\title{
Inactivation of Listeria monocytogenes in raw and hot smoked trout fillets by high hydrostatic pressure processing combined with liquid smoke and freezing
}

Article

Accepted Version

Creative Commons: Attribution-Noncommercial-No Derivative Works 4.0

Ekonomou, S. I., Bulut, S., Karatzas, K. A. G. and Boziaris, I. S. (2020) Inactivation of Listeria monocytogenes in raw and hot smoked trout fillets by high hydrostatic pressure processing combined with liquid smoke and freezing. Innovative Food Science \& Emerging Technologies, 64. 102427. ISSN 1466-8564 doi:

https://doi.org/10.1016/j.ifset.2020.102427 Available at https://centaur.reading.ac.uk/92140/

It is advisable to refer to the publisher's version if you intend to cite from the work. See Guidance on citing.

Published version at: http://dx.doi.org/10.1016/j.ifset.2020.102427

To link to this article DOI: http://dx.doi.org/10.1016/j.ifset.2020.102427

Publisher: Elsevier

All outputs in CentAUR are protected by Intellectual Property Rights law, including copyright law. Copyright and IPR is retained by the creators or other copyright holders. Terms and conditions for use of this material are defined in the End User Agreement. 


\section{www.reading.ac.uk/centaur}

\section{CentAUR}

Central Archive at the University of Reading

Reading's research outputs online 
1 Inactivation of Listeria monocytogenes in raw and hot smoked trout fillets by high

2 hydrostatic pressure processing combined with liquid smoke and freezing.

3 Ekonomou S.I. ${ }^{1,2}$, Bulut S. ${ }^{1,3}$, Karatzas K.A.G. ${ }^{1 *}$, Boziaris I.S. ${ }^{2}$

$5 \quad{ }^{1}$ Department of Food and Nutritional Sciences, The University of Reading, PO Box 6 226, Whiteknights, Reading RG6 6AP, UK.

${ }^{2}$ Lab. Marketing and Technology of Aquatic Products and Foods, Department of 10 Ichthyology and Aquatic Environment, School of Agricultural Sciences, University of 11 Thessaly, Fitokou street, 38446, N. Ionia, Volos, Greece

${ }^{3}$ Engineering Faculty, Food Engineering Department, Trakya University, Edirne, 15 Turkey

16

$17 *$ Corresponding author

18 Email address: k.karatzas@ @reading.ac.uk

19 Corresponding author address:

20 School of Chemistry, Food and Pharmacy

21 Department of Food \& Nutritional Sciences,

22 University of Reading,

23 Reading

24 RG6 6AD

25 UK

26

Tel. +44 1183786678

Fax. +441189310080

29

Email: k.karatzas@ reading.ac.uk 


\section{Abstract}

High hydrostatic pressure (HHP; $200 \mathrm{MPa}$ for $15 \mathrm{~min}$ ), in combination with liquid smoke and freezing was used to eliminate Listeria monocytogenes in BHI broth, raw and smoked trout. The bactericidal effect of liquid smoke (L9 and G6) solutions, HHP and their combinations were evaluated against L. monocytogenes LO28, EGD-e and $10403 \mathrm{~S}$ and further continued with the most resistant strain (10403S) to the combined treatment. For first time, a synergistic effect of liquid smoke and HHP was observed, further enhanced by freezing at $-80{ }^{\circ} \mathrm{C}$ prior to HHP. The effect of HHP and liquid smoke on L. monocytogenes $10403 \mathrm{~S}$, prior to freezing was highest in BHI compared to raw and smoked trout. However, major synergistic effect of HHP, liquid smoke and freezing was observed, reaching a $5.48 \log \mathrm{CFU} / \mathrm{g}$ reduction when smoked trout was used. High levels of injury also occurred, among the treatments on L. monocytogenes 10403S.

\section{Industrial relevance}

HHP is a novel, non-thermal technique that emerged in food protection within the last three decades and further knowledge needs to be generated. This paper illustrates for first time, the possibility of using a very low pressure in combination with liquid smoke and freezing to eliminate L. monocytogenes. It was demonstrated that treatment of trout samples with liquid smoke followed by freezing prior to pressurization at $200 \mathrm{MPa}$ for 15 min reduced the number of L. monocytogenes by more than $5 \log$ CFU/g. Such a remarkable bacterial inactivation at a very low pressure (compared to common industrial practices) is a significant achievement that could allow production of safer and novel products by HHP at an affordable price, as the cost of equipment manufacture 
as well as the maintenance and running costs could be reduced substantially at lower operation pressures.

Keywords: High Hydrostatic Pressure, Listeria monocytogenes, freezing, liquid smoke, sub-lethal injury, rainbow trout

\section{Introduction}

Fish and seafood are much appreciated because of their high nutritional value but are perishable and represent a high microbiological risk for the consumer (Novotny et al., 2004). According to the Food and Agriculture Organization (FAO, 2018), live, fresh or chilled seafood represent $45 \%$ of the world's human consumption, while cured (dried, salted, in brine, fermented smoked) seafood represent $12 \%$.

To extend the shelf life and maintain the quality of smoked fish, vacuum packaging is normally used, but to ensure food safety and to guarantee high product quality, strict temperature control of refrigeration storage is required. Listeria monocytogenes is a serious concern for consumer safety in ready-to-eat (RTE) products (Beaufort, 2011), because of the capability to survive under various conditions and even grow under refrigeration temperatures. The direct contamination of food processing equipment and subsequently foods with $L$. monocytogenes is easy as it is ubiquitous in nature and can result in outbreaks of foodborne disease called listeriosis, a rare but severe illness with a high mortality rate (>30\%; EFSA, 2015).

Although a broad range of preservation techniques are used to preserve seafood and control the growth of foodborne pathogens (Neil, 2012; Boziaris, 2014), microbial spoilage and food contamination remains a problem that needs to be controlled effectively (Khan et al., 2017). Furthermore, novel food processing methods, such as 
High Hydrostatic Pressure (HHP) offer solutions that can implement food safety and prolong the shelf life of fish (Erkan et al., 2010a) and RTE seafood products (Georget et al., 2015; Syed et al., 2016; Possas et al., 2017).

Nowadays, consumers desire minimally processed food products with less additives, but with improved safety and shelf-life (Spence, 2006; Sun-Waterhouse et al., 2014; Moses et al., 2014). HHP can provide food products with high retention of nutritional quality and minimal effects on the organoleptic characteristics (Rastogi \& Knorr, 2013).

During the last decades the use of this technique has been extended to various types of foodstuff, including fish and seafood (Elamin et al., 2015). Furthermore, several products processed with HHP are commercially available in regions of North America, Europe, Oceania and Asia. In seafood products, HHP is being used as a non-thermal technology for inactivation of bacterial pathogens and for reducing the spoilage microorganisms (Koutchma, 2014). One of the major disadvantages of HHP is the high cost of the initial investment which combined with the limited product output as a batch process, which results in limited application in the food industry. Therefore, the majority of the scientific work in HHP aims at the reduction of the applied pressure which could translate into lower wear of the equipment or shorter processing times resulting in higher product output and lower prices. This is normally achieved by following the principles of the "Hurdle Technology", as defined by Leistner (1992).

Freezing is an excellent preservation method to delay or prevent microbial growth and preserve the organoleptic characteristics of fresh products (Olivera \& Salvadori, 2009; Leygonie et al., 2012). Rapid freezing methods are generally preferred to avoid the formation of large ice crystals, which can cause mechanical damage and downgrade the product's appearance (Zatirsky, 2011). HHP application has the potential to improve the kinetics of freezing and the characteristics of ice crystals formed in the product 
107 (Sanz \& Otero, 2014). Phase transitions of ice crystals during the pressurization of 108 frozen food have been previously suggested to take place during the HHP treatment 109 that results in cellular damage and increased microbial inactivation (Luscher et al., 110 2004; Shen et al., 2005; Su et al., 2014a). Several studies have proposed that the 111 application of HHP on frozen products at low or subzero temperatures and atmospheric 112 conditions can enhance the microbial inactivation and thus allow the usage of lower 113 pressure treatments (Knorr et al., 1998; Fernández et al., 2007; Vaudagna et al., 2012; 114 Bulut, 2014a; Bulut, 2014b; Albertos, 2016; Parlapani et al., 2019). The effectiveness 115 of the combined HHP and freezing treatment depends on the characteristics of the 116 product $\left(\mathrm{pH}, \mathrm{a}_{\mathrm{w}}\right.$, composition, etc.), on the type of the tested microorganism and on the

117 process conditions (pressure level, holding time and temperature; Sanz \& Otero, 2014; 118 Choi, 2008; Park et al., 2008).

119 The application of liquid smoke condensates is lately used on meat, fish and poultry as 120 an alternative modern technique for smoking of foods, which requires less time than 121 traditional smoking, produces less wastes and polycyclic aromatic hydrocarbons 122 (PAHs) to the environment or the smoked products (Hattula et al. 2001; EFSA, 2007; 123 Lingbeck et., 2014). Smoked food products contain PAHs, but many researchers have 124 demonstrated that using smoke flavorings instead of traditional smoking procedure led 125 to no detectable carcinogenic PAHs or to high reduction of their concentration in the 126 final product (Gomaa et al., 1993; Muratore et al., 2007; Dimitriadou et al., 2008; 127 McDonald, 2015). Liquid smoke condensates are produced by the wood smoke 128 generated from sawdust or untreated wood, by the controlled process of minimal 129 oxygen pyrolysis (IOFI, 2012). The main compounds in liquid smoke are phenols, acids 130 and carbonyls. In particular, phenolic compounds are responsible for the characteristic 
131 aroma and flavor of a smoked product and the carbonyls can also give a sweet aroma

132 and color by browning reaction (Theobald et al., 2012; Fasano et al., 2016).

133 It is known that phenols can damage the bacterial membrane while carbonyl compounds

134 can penetrate the cell wall and inactivate enzymes of the cytoplasm and the

135 cytoplasmatic membrane (Lingbeck et., 2014). There are numerous studies indicating

136 that liquid smoke showed inhibitory effects against foodborne pathogens such as $L$.

137 monocytogenes, Aeromonas hydrophila, Yersinia enterocolitica, Escherichia coli etc.

138 in RTE products (Montazeri et al., 2013; Suñen et al., 2001; Van Loo et al., 2012).

139 Yousef and Courtney (2002), proposed that cell membrane damage, leads to their

140 microbial death after HHP treatment. This can affect the cell membrane permeability,

141 disrupt the protein structure and function, make the pathogen more vulnerable under 142 the presence of antimicrobial agents, such as carbonyls or phenols, contained into liquid 143 smoke condensates.

144 Smoked fish are normally RTE foods and HHP treatment could increase the product 145 quality and further reduce the microbial load. Furthermore, it is possible to introduce a 146 freezing stage prior to HHP treatment and reduce the microbial load even further, 147 possibly reduce the pressurization times and still maintain a high-quality product 148 (Vaudagna et al., 2012; Bulut, 2014a). To the best of the authors' knowledge, this is the

149 first time that the application of HHP was investigated on a frozen product treated with

150 liquid smoke against L. monocytogenes, a pathogen that has been previously associated 151 with smoked fish.

\section{2. Materials \& methods}

154 2.1. Bacterial cultures 
155 Three different commonly used reference strains of L. monocytogenes (LO28, EGD-e 156 and 10403S) were used in this study. LO28 is a serotype 1/2c, while EGD-e and 10403S

157 both belong to serotype 1/2a. All bacterial strains were kept in cryovials supplemented 158 with $7.0 \%$ (vol/vol) dimethyl sulfoxide (DMSO; Sigma-Aldrich, Dorset, UK) at -80

$159{ }^{\circ} \mathrm{C}$. Before experiments, strains were streaked onto Brain Heart Infusion (BHI) agar

160 (LABM, Lancashire UK) and incubated overnight at $37^{\circ} \mathrm{C}$. A single colony from each 161 plate was transferred with a sterile loop in $3 \mathrm{~mL}$ of BHI (LAB M, Lancashire UK) and 162 incubated overnight at $37^{\circ} \mathrm{C}$ without shaking. To prepare the final working cultures, 20 $163 \mathrm{~mL}$ sterile BHI were inoculated with the overnight culture and left for incubation at 37

$164{ }^{\circ} \mathrm{C}$ for $24 \mathrm{~h}$ without shaking. Cultures from stationary phase were harvested by 165 centrifugation (Heraeus ${ }^{\mathrm{TM}}$ Multifuge ${ }^{\mathrm{TM}} \mathrm{X} 3$ Centrifuge, Thermo Scientific, UK) at 9000 $166 \times \mathrm{g}$ for $5 \mathrm{~min}$ (room temperature), washed twice using sterile Phosphate-buffered saline 167 (PBS pH 7.1; Oxoid, Basingstoke, UK) and re-suspended in the same medium. Further 168 serial decimal dilutions were prepared for direct plating on BHI agar. The plates were 169 incubated for $24 \mathrm{~h}$ at $37^{\circ} \mathrm{C}$ and viable cell number was expressed as log CFU/mL.

\subsection{Liquid smoke extracts preparation}

172 All liquid smoke fractions were provided by "Ruitenberg Ingredients B.V. (Twello, the

173 Netherlands). The liquid smoke condensates coded as L9 and G6 were chosen as the 174 most effective following preliminary experiments. L9 is a coloring product mainly used 175 upon heating, containing about $350 \mathrm{~g} / \mathrm{l}$ carbonyls and $1 \mathrm{~g} / \mathrm{l}$ phenols, while G6 is a true 176 smoke condensate fraction with high carbonyl content $(160 \mathrm{~g} / \mathrm{l})$ and also lower phenol 177 compounds $(0.0-2.0 \mathrm{~g} / \mathrm{l})$. According to specifications, both extracts may contain a 178 maximum content of $10 \mathrm{ppb}(0.01 \mathrm{mg} / \mathrm{kg})$ benzo[a]pyrene and $20 \mathrm{ppb}(0.02 \mathrm{mg} / \mathrm{kg})$ 

benzo[a]anthracene $(\mathrm{BaP})$, are derived from non-genetically modified organisms (nonGMO) and Generally Regarded as Safe (GRAS) by FDA and are also USDA approved. The working stock solutions of liquid smoke condensates were prepared with filtration through a $0.22 \mu \mathrm{m}$ pore size membrane filter (Durapore, Millipore) directly to sterilize and finally to store at $2{ }^{\circ} \mathrm{C}$.

\subsection{Resistance of L. monocytogenes strains to liquid smoke fractions}

Harvested cells were suspended into sterile Universal Polystyrene Containers (Sterilin, UK) with $10 \mathrm{~mL}$ liquid smoke solutions in BHI broth of final concentrations ranging from $0.25 \%$ to $1.00 \%(\mathrm{v} / \mathrm{v})$ in 0.25 increments. The initial population was fixed at $10^{9}$ $-10^{10} \mathrm{CFU} / \mathrm{mL}$ for each strain individually. Subsequently, the samples were left for incubation at $37^{\circ} \mathrm{C}$. Samples of $1 \mathrm{~mL}$ were taken after 0, 30, 60 and $180 \mathrm{~min}$. Decimal dilution of samples were prepared in Maximum Recovery Diluent (MRD), (Oxoid, Basingstoke, UK), into sterile Eppendorf tubes, and $25 \mu \mathrm{L}$ from each dilution and also directly from the BHI broth (zero dilution) were plated onto BHI agar using the spot plate method adapted from Laubacher and Ades (2008) and incubated for $24 \mathrm{~h}$ at $37^{\circ} \mathrm{C}$. The limit of detection was $1.60 \log \mathrm{CFU} / \mathrm{mL}$.

\subsection{Sample preparation for HHP}

\subsubsection{Preparation of BHI broth samples}

After $24 \mathrm{~h}$ incubation at $37{ }^{\circ} \mathrm{C}, 10 \mathrm{~mL}$ volumes of BHI containing about $10^{9}-10^{10}$ CFU/mL cell population, were placed into sterile Stomacher bags (Worthing, UK). Also, sterile BHI broth containing $3.80 \%$ (w/v) $\mathrm{NaCl}$ was prepared. Subsequently, all samples were heat-sealed after removing all air as described by Bulut (2014b) and finally placed individually into a second plastic bag made of polyamide/polyethylene 
and vacuum packed for 30 s using a Fresco 300 Packaging Machine

205 (SousVidetools.com).

\subsubsection{Preparation of trout samples}

208 Raw and hot smoked trout (Oncorhynchus mykiss) fillets obtained from a local store 209 (Reading, UK). Samples were cut uniformly in chunks of $5 \mathrm{~g}$ (approx. $35 \mathrm{~mm} \times 45 \mathrm{~mm}$ $210 \times 10 \mathrm{~mm})$, sprayed on with $70 \%(\mathrm{v} / \mathrm{v})$ alcohol and placed on a rack with no contact 211 between the samples to evaporate the excess alcohol. A $3.80 \%$ (w/v) $\mathrm{NaCl}$ sterile 212 solution was prepared and $100 \mu \mathrm{L}$ was added on raw and hot smoked trout chunks. The 213 samples were then inoculated with $100 \mu \mathrm{L}$ of the L. monocytogenes $10403 \mathrm{~S}$ bacterial 214 suspension which gave a final concentration of about $10^{7} \mathrm{CFU} / \mathrm{g}$. Subsequently, $100 \mu \mathrm{L}$ 215 of $0.50 \%$ L9 or G6 liquid smoke extract was added on the chunks. As a control, 100 $216 \mu \mathrm{L}$ sterile water was added on the fish samples. All inoculations (salt, sterile water, 217 liquid smoke and L. monocytogenes inoculum) were done to the upper surface of the 218 chunks. A sterile spatula vas used to spread the inoculums on the surface of the chunks.

219 The samples were then heat sealed and vacuum packed. Finally, the samples were 220 separated into two groups and half were pressure-treated while the other half, were left 221 overnight at $-80{ }^{\circ} \mathrm{C}$ inside a high efficiency upright ultra-low temperature freezer

222 (Eppendorf HEF U570, New Brunswick, Germany) before being pressure-treated.

223 All samples were microbiologically analyzed in triplicate while, non-treated samples, 224 without pressure treatment or freezing, were also analyzed.

\subsection{HHP treatment set up and operation mode}

227 All samples were pressure-treated at $200 \mathrm{MPa}$ for $15 \mathrm{~min}$, as one of the lowest in the 228 food industry. A laboratory-scale high-pressure system (Stansted Fluid Power Products 
229 Ltd., Harlow, UK) with $40 \mathrm{~mm}$ internal diameter vessel and $250 \mathrm{ml}$ working volume 230 was used. The pressure transmitting medium (PTM) used was 30\% (v/v) aqueous 231 solution of mono propylene glycol (Sigma-Aldrich, Dorset, UK). A cooling circulator 232 (Grant LTD6G, UK) was used to circulate the water containing mono propylene glycol 233 as antifreeze, in the jacket surrounding the pressure vessel to control and maintain the 234 processing temperature measured through the PTM inside the pressure chamber. 235 Packed samples treated in room temperature were immediately placed into the pressure 236 chamber. Frozen samples at $-80{ }^{\circ} \mathrm{C}$ were removed from the freezer and immediately 237 placed in the working vessel which was kept at $0-1{ }^{\circ} \mathrm{C}$. The time needed to remove the 238 samples from the freezer and place them in the HHP vessel was less than $20 \mathrm{~s}$ suggesting 239 that the temperature was still close to $-80{ }^{\circ} \mathrm{C}$. The pressure come-up time was about $240100 \mathrm{MPa} / 10 \mathrm{~s}$, while decompression time was less than $5 \mathrm{~s}$. The chamber temperature 241 was monitored and recorded by a K-type thermocouple mounted to the center of the top 242 closure of the pressure chamber.

243 Untreated inoculated BHI broth (without liquid smoke), raw trout and smoked trout, 244 vacuum packaged samples were used as control samples, and non-treated (without HHP 245 treatment or without freezing) were used as blank samples.

\subsection{Bacterial enumeration and evaluation of injury}

248 To determine the microbiological count in broth samples, $100 \mu \mathrm{L}$ were removed and 249 serial decimal dilutions were prepared in $900 \mu \mathrm{L}$ MRD (Oxoid, Basingstoke, UK), into 250 sterile Eppendorf tubes. For fish samples, $5 \mathrm{~g}$ were removed aseptically using a sterile 251 scalpel and placed into a sterile Stomacher bag (Worthing, UK) containing $45 \mathrm{~mL}$ 252 MRD. Bags were stomached for $90 \mathrm{~s}$ and $25 \mu \mathrm{L}$ were removed from the appropriate 253 serial decimal dilution and were placed onto BHI agar using the spot plate method and 
254 incubated for $24 \mathrm{~h}-72 \mathrm{~h}$ at $37{ }^{\circ} \mathrm{C}$. The limit of detection for all fish samples was 2.60

$255 \log \mathrm{CFU} / \mathrm{g}$. To verify the amount of sublethal injury, samples were also placed in 256 parallel onto the selective medium Brilliance ${ }^{\mathrm{TM}}$ Listeria Agar (OXOID, Wesel, 257 Germany) and plates were incubated at $37^{\circ} \mathrm{C}$ for $24 \mathrm{~h}-72 \mathrm{~h}$.

258 To calculate the percentage of sub lethally injured cells after freezing, HHP treatment 259 and liquid smoke extracts (L9 or G6), the following equation (Dykes, 1999; Wang et 260 al., 2017) was used based on the viable counts' differences on non-selective $\left(\mathrm{N}_{\text {non- }}\right.$ 261 selective $)$ and selective media $\left(\mathrm{N}_{\text {selective }}\right)$ :

$$
\% \text { Sublethal Injury }=\frac{N_{\text {non-selective }}-N_{\text {selective }}}{N_{\text {non-selective }}} \times 100
$$

\subsection{Experimental design}

265 All samples were taken in triplicate (biological replicates) while each biological 266 replicate was analyzed with two technical replicates. Data plotting and statistical 267 analysis by calculating mean values was performed using Excel Microsoft@ Office 365 268 (ver. 16.18). To assess the differences between the tested treatments one-way analysis 269 (ANOVA) was performed and Tukey post hoc test was used to compare sample data 270 with the use of the IBM ${ }^{\circledR}$ SPSS $^{\circledR}$ statistics 19 software, for Windows (SPSS Inc.,U.S.). 271 For data that showed a normal distribution, the Student's t-test was used to determine 272 significance. Level of significance was defined as $5.00 \%$, and thus values with $\mathrm{P}<0.05$ 273 were considered significant.

\section{Results}


The behavior of the different strains in BHI broth, against the two liquid smoke extracts (L9 and G6) was assessed (Fig. 1). The population of L. monocytogenes 10403S WT, LO28 WT, and EGD-e WT strains after $180 \mathrm{~min}$ in BHI broth without added liquid smoke (control), was 9.42, 9.22 and $8.89 \log \mathrm{CFU} / \mathrm{mL}$, respectively (Fig. 1). Following 281 exposure for $180 \mathrm{~min}$, in BHI broth supplemented with $1.00 \%$ (v/v) L9 or G6, $L$. monocytogenes $10403 \mathrm{~S}$ WT resulted in a significant drop in bacterial numbers that reached below the detection limit of $1.60 \log \mathrm{CFU} / \mathrm{mL}$ corresponding to a higher than $7.70 \log$ reduction of CFU/mL (Fig. 1A). Furthermore, bacterial numbers of LO28 WT and EGD-e WT dropped below the detection limit, after $180 \mathrm{~min}$, in BHI broth supplemented with $0.75 \%$ and $1.00 \%$ L9 corresponding to 7.50 and 7.12 log reduction of CFU/mL, respectively. In contrast, to L9 the effect of G6 $1.00 \%$ was significantly ( $<<0.05)$ lower showing a reduction of 3.13 and $3.15 \log \mathrm{CFU} / \mathrm{mL}$, for LO28 and EGD-e, respectively (Fig. 1B \& C). After $1 \mathrm{~h}$ the results varied among the different $L$. monocytogenes strains while again L9 $0.75 \%$ and $1.00 \%$ was significantly more 291 effective than G6 for the same concentrations against LO28 WT and EGD-e WT. 292 Logarithmic reduction of LO28 WT and EGD-e WT after 60 min with $0.50 \%$ and 0.75 $293 \%$ G6 was less than $0.50 \log \mathrm{CFU} / \mathrm{mL}$, while after exposure to $0.75 \% \mathrm{~L}$, a reduction 294 of 1.57 and $1.53 \log$ CFU/mL was reached, for LO28 WT and EGD-e WT, respectively 295 (Fig. 1B \& C). The population of 10403S WT after $1 \mathrm{~h}$ of exposure to L9 $0.50 \%, 0.75$ $296 \%$ and $1.00 \%$ showed a reduction of $0.86,1.69$ and $2.49 \log$ CFU/mL, respectively. 297 Against the highest concentration of $1.00 \%$ G6 after $1 \mathrm{~h}$, the counts of 10403S WT 298 reached a reduction of $0.83 \log \mathrm{CFU} / \mathrm{mL}$ (Fig. 1A).

299 Our results showed that following a 30 min exposure, the antimicrobial activity was 300 similar for all the subjected strains with no significant population reduction that was 301 not higher than $0.50 \log \mathrm{CFU} / \mathrm{mL}$ (Fig. 1A, B \& C). 
303 3.2. Effect of HHP and liquid smoke extracts on L. monocytogenes strains

304 As our aim was to use liquid smoke and freezing as additional hurdles to reduce the 305 intensity of an HHP treatment, further experiments were carried out with shorter 306 exposure times of $15 \mathrm{~min}$ (HHP treatment time) at $0.50 \%(\mathrm{v} / \mathrm{v})$ concertation (unless 307 otherwise stated) of liquid smokes L9 and G6. The samples that were exposed to liquid 308 smoke (L9 or G6) for 15 min without HHP treatment resulted in $<0.20$ log reductions 309 of CFU/mL, regardless of containing $\mathrm{NaCl}$ or not (Fig. $2 ; \mathrm{p}>0.05$ ). Pressure treatment 310 of BHI broth samples without liquid smoke (control) at $200 \mathrm{MPa}$ for 15 min resulted in 311 minor reductions of 0.15 and $0.65 \log \mathrm{CFU} / \mathrm{mL}$ for the samples with $\mathrm{NaCl}$ and without $312 \mathrm{NaCl}$, respectively (Fig. 2; p > 0.05).

313 The HHP treatment in combination with L9 or G6 caused a significant population 314 reduction of all L. monocytogenes strains tested. As expected, the results among the 315 different strains varied with the highest $\log$ reduction of $4.75 \log \mathrm{CFU} / \mathrm{mL}$ and $3.85 \log$ $316 \mathrm{CFU} / \mathrm{mL}$ achieved for L. monocytogenes LO28 supplemented with $0.50 \%(\mathrm{v} / \mathrm{v}) \mathrm{G} 6$ 317 without and with $\mathrm{NaCl}$, respectively (Fig. 2; p < 0.05). HHP treatment combined with 318 the most effective extract G6 resulted in 2.64 and $2.97 \log$ CFU/mL reduction in 319 number of L. monocytogenes EGD-e for the samples without salt and with salt, 320 respectively (Fig. 2; p > 0.05). Pressure treatment for L. monocytogenes 10403S in BHI 321 supplemented with G6 resulted in $\log$ reductions of 2.56 and $1.80 \mathrm{CFU} / \mathrm{mL}$ for the 322 samples with and without salt, respectively (Fig. $2 ; \mathrm{p}<0.05$ ).

323 HHP treatment of BHI broth samples with $\mathrm{L} 9$ (no $\mathrm{NaCl}$ ) reduced the number of $L$. 324 monocytogenes LO28, EGD-e and $10403 \mathrm{~S}$ by $2.10,1.40$ and $1.12 \log \mathrm{CFU} / \mathrm{mL}$, 325 respectively (Fig. 2; p < 0.05). When BHI broth samples supplemented with L9 and $326 \mathrm{NaCl}$ were pressure treated under the same conditions, 2.55, 1.42 and $1.44 \log \mathrm{CFU} / \mathrm{mL}$ 
reductions were obtained in number of L. monocytogenes LO28, EGD-e and 10403S, respectively (Fig. 2).

329 Under the conditions tested, L. monocytogenes $10403 \mathrm{~S}$ was the most resistant to the

330 combined treatment compared to the other two strains. Therefore, further experiments

331 were carried out by using L. monocytogenes strain $10403 \mathrm{~S}$ as test microorganism.

3.3. Application of HHP and freezing at $-80^{\circ} \mathrm{C}$ in broth, raw trout and hot smoked trout samples.

335 Following the investigation of the combined effect of HHP and liquid smoke, we 336 investigated the possibility of applying these technologies in frozen broth, raw and hot 337 smoked trout at $-80{ }^{\circ} \mathrm{C}$ as an additional hurdle to further increase the inactivation of $L$. monocytogenes 10403S. As seen in Fig. 3, the samples containing liquid smoke L9 or

339 G6 with or without salt showed no significant differences in the absence of pressure 340 treatment and the log reduction remained below 0.50, regardless of the samples being 341 frozen or not. The effect of HHP without addition of liquid smoke, on L. monocytogenes $34210403 \mathrm{~S}$ was statistically significant $(\mathrm{p}<0.05)$ but minimal $(0.73 \log \mathrm{CFU} / \mathrm{mL})$. On the 343 other hand, HHP combined with freezing at $-80{ }^{\circ} \mathrm{C}$, without liquid smoke, resulted in $3442.35 \log$ CFU/mL reduction (Fig. 3). Similar results were obtained for the samples, 345 supplemented with $\mathrm{NaCl}$ where $3.00 \log$ reduction increased from $0.51 \log \mathrm{CFU} / \mathrm{mL}$ to $3463.17 \mathrm{CFU} / \mathrm{mL}$ as a result of freezing the samples before the pressure treatment (Fig. 3; $347 \mathrm{p}>0.05)$.

348 For the samples that were at room temperature before the pressure treatment, addition 349 of salt to liquid smoke increased the $\log$ reduction from 1.85 to $3.07 \mathrm{CFU} / \mathrm{mL}$ for L9 350 and from 2.53 to $3.07 \mathrm{CFU} / \mathrm{mL}$ for G6 (Fig. 3; $\mathrm{p}<0.05$ ). However, when the pressure351 treated samples with or without $\mathrm{NaCl}$, before freezing supplemented with $0.50 \%(\mathrm{v} / \mathrm{v})$ 
352 G6, a reduction of 3.07 and $2.53 \log$ CFU/mL, was obtained (Fig. 3; p > 0.05). Addition

353 of salt to the samples containing liquid smoke which were then frozen at $-80^{\circ} \mathrm{C}$ before

354 pressure treatment caused a slight decrease in log reductions for L9 (from 3.23 to 2.94

$355 \log \mathrm{CFU} / \mathrm{mL}$ ) and made no significant difference for G6 (from 2.94 to $2.90 \log$

$356 \mathrm{CFU} / \mathrm{mL})$.

357 The application of HHP treatment in combination with smoke on raw rainbow trout 358 chunks resulted in a limited reduction in number of L. monocytogenes $10403 \mathrm{~S}$ in both 359 the presence and absence of salt. As seen in Fig. 4, maximum log reduction remained 360 below $0.42 \log \mathrm{CFU} / \mathrm{g}$ at all conditions tested for the samples that were at room 361 temperature before the pressure treatment. HHP treatment of raw rainbow trout chunks 362 frozen at $-80{ }^{\circ} \mathrm{C}$ before the pressure treatment resulted in significant reduction in 363 number of L. monocytogenes $10403 \mathrm{~S}$ for all the treatments (Fig. 4). HHP treatment of 364 frozen raw rainbow trout chunks without liquid smoke, containing or not salt, reduced 365 the population of L. monocytogenes $10403 \mathrm{~S}$ by 1.60 and $1.37 \log$ CFU/g, respectively 366 (Fig. 4; p > 0.05). In the absence of salt, treatment of samples with L9 and G6 and then 367 freezing before the pressure treatment increased the bacterial death to 1.93 and $1.80 \log$ 368 (CFU/g), respectively (Fig. 4). In the presence of salt, pressure treatment of frozen 369 samples with L9 and G6 resulted in 1.54 and $1.68 \log (\mathrm{CFU} / \mathrm{g})$ reductions, respectively $370 \quad$ (Fig. 4; $\mathrm{p}>0.05)$.

371 Subsequently, we assessed the effect of HHP treatment in combination with liquid 372 smoke on L. monocytogenes $10403 \mathrm{~S}$ inoculated on hot smoked trout. In the absence of 373 freezing, pressure treatment of inoculated hot smoked trout samples resulted in only $3740.25 \log$ reduction of CFU/g (Fig. 5). Furthermore, the addition of liquid smoke on the 375 surface of the fish without freezing, after HHP, also resulted in a minimal effect of 0.29 376 and $0.26 \log$ CFU/g for L9 and G6, respectively (Fig. 5; p > 0.05). In addition, also 
freezing at $-80{ }^{\circ} \mathrm{C}$ by itself resulted in no reduction of CFU/g (data not shown). HHP treatment of inoculated hot smoked trout chunks (with no liquid smoke) after they were frozen at $-80{ }^{\circ} \mathrm{C}$ did not cause a significant reduction $(0.46 \log \mathrm{CFU} / \mathrm{g})$ in the numbers of L. monocytogenes $10403 \mathrm{~S}$. However, the same samples, upon supplementation with $0.50 \%(\mathrm{v} / \mathrm{v}) \mathrm{L} 9$ or G6, resulted in log reduction of CFU/g that was beyond 5.48 logs $382 \quad(n=6$, Fig. $5 ; \mathrm{p}<0.05)$.

\subsection{Sublethal injury of L. monocytogenes 10403S WT strain}

The percentage of sub lethally injured cells in BHI broth and on raw and smoked trout chunks, without freezing, was quite high for the samples containing L9 or G6 without added NaCl. More specifically, when G6 combined with HHP, prior freezing, caused the highest level of injury on bacterial cells, while freezing did not cause any significant changes. The percentage of injury after $\mathrm{HHP}$ and without freezing at $-80{ }^{\circ} \mathrm{C}$ for BHI broth and raw trout chunks was $51.49 \% \pm 19.82 \%$ and $32.79 \% \pm 10.11 \%$, respectively

391 showing no significant differences among the treatments, prior freezing $(p>0.05$; Table $3921)$.

393 It is noteworthy to highlight that freezing at $-80{ }^{\circ} \mathrm{C}$ in combination with HHP, caused 394 high injury levels. The maximum level of bacterial injury effect observed for pressure395 treated cells in BHI broth. The injury for BHI broth samples without and with salt, after 396 freezing, without liquid smoke additives was significantly different in comparison with 397 the samples without freezing $\left(20^{\circ} \mathrm{C}\right)$ and equal with $55.98 \% \pm 8.64 \%$ and $55.23 \% \pm$ $3983.93 \%$ (Table 1; $\mathrm{p}<0.05$ ). Pressure-treated BHI broth samples with freezing and L9 399 or $\mathrm{G} 6$ without $\mathrm{NaCl}$ content, compared with the same samples prior freezing, showed 400 no significant differences (Table $1 ; \mathrm{p}>0.05$ ). Though the percentage of injury for BHI 401 broth, with $\mathrm{NaCl}$ and $\mathrm{L} 9$, before freezing was $15.12 \% \pm 4.81 \%$, while after freezing 
was increased significantly and was equal with $55.86 \% \pm 1.24 \%$ (Table $1 ; \mathrm{p}<0.05$ ).

403 Table 1 also illustrates that G6 addition in BHI broth caused significant changes to the 404 percentage of sub lethal injury of L. monocytogenes for the samples with or without 405 salt.

406 The L. monocytogenes cells inoculated on the surface of raw trout chunks, also revealed 407 high injury for all treated samples as shown in Table 1. For raw trout chunks prior 408 freezing, without $\mathrm{NaCl}$, significant differences observed only among the samples with G6 (32.79 \% $\pm 10.11 \%)$ and without liquid smoke $(10.87 \% \pm 3.56 \%)$. Concurrent 410 application of freezing with HHP treatment on raw trout, caused sublethal injury of $L$. 411 monocytogenes cells, equal with $36.11 \% \pm 5.58 \%$ and $26.92 \% \pm 5.61 \%$ for the 412 samples supplemented with $\mathrm{L} 9$, containing or not $\mathrm{NaCl}$, respectively (Table $1 ; \mathrm{p}<$ 413 0.05). However, pressure-treated raw trout samples after freezing, containing or not 414 salt, showed no significant differences (Table 1).

415 As seen in Table 1, the differences of sub lethal injury of L. monocytogenes cells found 416 in smoked trout chunks without liquid smoke, submitted in freezing at $-80{ }^{\circ} \mathrm{C}$, prior to 417 HP treatment $(38.59 \% \pm 3.15 \%)$ were significant comparing with the same samples 418 stayed at $20{ }^{\circ} \mathrm{C}(14.31 \% \pm 1.23 \%)$ (Table $\left.1 ; \mathrm{p}<0.05\right)$. When the smoked trout 419 supplemented with $\mathrm{L} 9$ or $\mathrm{G} 6$ without $\mathrm{NaCl}$, prior freezing and followed by $\mathrm{HHP}$ 420 treatment, no significant differences observed, while after freezing no injury on 421 bacterial cells detected (Table 1). During the investigation of the treatments on hot 422 smoked trout fillets, no extra $\mathrm{NaCl}$ added to an already salted product to better evaluate 423 the real conditions.

\section{Discussion}


426 The current study investigates the behavior of L. monocytogenes strains in a liquid 427 medium and hot smoked or raw trout upon the application of different treatments, such 428 as HHP, freezing and smoking. In the current work, only one type of HHP treatment 429 (200 MPa for $15 \mathrm{~min}$ ), was used, which is one of the lowest, if not the lowest in the 430 food industry (Koutchma, 2014; Khan et al., 2017). The first hurdle introduced in 431 combination with HHP was liquid smoke. Two water-soluble liquid smoke condensates 432 (L9 and G6) were used, as common preservatives for protein-based foods, such as 433 seafood. The smoke extracts against all three strains was effective in a dose and 434 exposure time-related pattern. Nowadays traditional smoking is primarily used to 435 endow the typical characteristics of aroma, flavor and color to the smoked products 436 (Theobald et al., 2012; Fasano et al., 2016) but the controlled use of liquid smoke 437 extracts can inhibit the growth of foodborne pathogens (Lingbeck et al., 2014). There 438 are several studies, presenting the in vitro antimicrobial effect of liquid smokes against 439 foodborne pathogens, such as Aeromonas hydrophila (Sofos et al., 1988; Suñen et al., 440 2003), Yersinia enterocolitica (Suñen et al., 2001), pathogenic Escherichia coli 441 (Schmid-Hempel \& Frank, 2007; Van Loo et al., 2012) and L. monocytogenes (Martin 442 et al., 2010; Pittman et al., 2012; Morey, et al., 2012). In previous work Vitt et al. 443 (2001), tested 5 commercial liquid smoke extracts at varying concentrations to estimate 444 the inhibitory effect on L. innocua and L. monocytogenes and found that $0.50 \%$ liquid 445 smoke inhibited L. innocua in BHI broth. This is in agreement with our work where $4460.50 \%$ liquid smoke resulted in minor but measurable reductions in the $L$. 447 monocytogenes numbers suggesting that such a concentration would be inhibitory in 448 our experimental setup. It is well established that great differences may occur in stress 449 resistance between individual strains and therefore the most tolerant strains should be 450 considered to better assess, the food safety risks posed by tolerant strains and develop 
methods to control the growth and survival of the pathogen in the final product (Lunden 452 et al., 2008; Carpentier \& Cerf, 2011; Ferreira et al., 2014; Heir et al., 2018). The liquid 453 smokes used contain high carbonyls and low phenolic compounds.

454 In the present work, the application of $\mathrm{HHP}$ at $200 \mathrm{MPa}$ for $15 \mathrm{~min}$ on BHI broth 455 samples (without liquid smoke) resulted in a minor $\log$ reduction of CFU/mL with no 456 significant differences among L. monocytogenes strains. The presence or absence of 457 salt in BHI broth did not have any effect, while both liquid smoke extracts enhanced 458 the lethal effect of HHP. The liquid smoke and HHP showed a synergistic effect while 459 the addition of salt had no major effect for most of the samples, with only exception the 460 samples of L. monocytogenes LO28 and EGD-e with or without salt and G6, where the 461 differences observed, were significantly different ( $p<0.05$; Fig. 2). This demonstrates 462 that it is possible to enhance the antimicrobial effects of HHP with the use of smoke or 463 vice-versa. Exposure of L. monocytogenes to liquid smoke (L9 or G6) in BHI broth for 46430 min resulted in a minor reduction, less than $0.50 \log \mathrm{CFU} / \mathrm{mL}$ (Fig. 1A, B \& C). 465 From all three strains, LO28 represents a normal strain of L. monocytogenes, while 466 EGD-e is a lab strain with extreme resistance to oxidative stress and 10403S an 467 extremely acid resistant strain which might be linked to its increased resistance to the 468 combined HHP and liquid smoke treatment. However, the combined treatment of 469 extremely low HHP and low levels of liquid smoke is able to bring about more than $470 \quad 4.00 \log$ reduction of $\mathrm{CFU} / \mathrm{ml}$ for a normal L. monocytogenes strain, such as LO28 and 471 this is promising.

472 Subsequently, we introduced freezing prior to HHP treatment. Freezing combined with 473 HHP showed to exert antimicrobial effects as shown previously (Bulut, 2014a; 2014b; 474 Su et al., 2014b). The liquid smoke enhanced the antimicrobial effects of HHP and 475 freezing, but this additional effect was not major. In contrast the impact of liquid smoke 
under HHP without freezing is major. This could be possibly due to the state of liquid

477 smoke under freezing conditions, which went through phase changes while it has

478 freezing point lower than water (Ledford, 1981) but further work is required to

479 investigate this. When freezing is performed properly, without multiple freezing steps,

480 food quality is minimally affected (Oosterhuis, 1981; Evans, 2009). Redmond et al.

481 (2003), used a liquid nitrogen cryogenic environmental chamber to freeze mashed

482 potatoes, were the pots of potato placed at $-90{ }^{\circ} \mathrm{C}$ reached an internal temperature of -

$48325{ }^{\circ} \mathrm{C}$ within 24 min compared to 78 min for samples frozen at $-30{ }^{\circ} \mathrm{C}$ with similar

484 results for fresh mashed potato.

485 Regarding the microbial safety, it is well established that freezing can induce high rates 486 of injury to the bacterial population. Jiang et al. (2011), revealed that, frozen storage at $487-18{ }^{\circ} \mathrm{C}$ as a pretreatment, followed by chill storage at $4{ }^{\circ} \mathrm{C}$ in combination with surface application of antimicrobials on roasted turkey, reduced significantly the initial population of L. monocytogenes. Golden et al. (1988), mentioned that, after 2 weeks at $490-18{ }^{\circ} \mathrm{C}$, the injury level of $L$. monocytogenes strains, reached up to $82 \%$. Our results 491 for L. monocytogenes after freezing, followed by HHP treatment, revealed high injury 492 levels, for BHI broth samples (Fig. 3).

493 Moreover, when L. monocytogenes 10403S was inoculated on the surface of sterile raw 494 trout chunks and subjected to HHP a limited lethal effect $(<0.40 \log$ reduction of $495 \mathrm{CFU} / \mathrm{g}$ ) was observed without freezing which was significantly lower than that 496 observed in BHI cultures. This is possibly due to constituents on the trout that might 497 protect the cells from the combined effect of HHP. The type, composition and the 498 matrix of the tested food seems to have an impact on the resistance of bacteria at HHP 499 (Bucur et al., 2018). Freezing also resulted to higher injury levels for L. monocytogenes 500 cells on raw trout chunks compared to those without freezing. As seen in BHI 
experiments, also on these raw trout experiments we observed that liquid smoke elicited hardly any antimicrobial effect under freezing temperature for the samples without HHP (Fig. 4). However, when we added this low concentration of liquid smokes (0.50 $\%$ ) on already smoked trout chunks we observed an impressive 5.48 log reduction of

$505 \mathrm{CFU} / \mathrm{g}$ following freezing at $-80^{\circ} \mathrm{C}$ and $\mathrm{HHP}$ (Fig. 5). In this case the increased concentration of smoke contributed the above major synergistic effect while in its absence, the observed reduction was less than $0.50 \mathrm{log}$ (CFU/g) (Fig. 5). We also demonstrate that this major synergistic effect could be used to significantly decrease the HHP intensity which could translate to major reduction in economic costs.

510 Working with cold-smoked salmon, Vitt et al. (2001), observed that a much higher 511 concentration than $0.50 \%$ of liquid smoke was required to inhibit L. innocua or $L$. monocytogenes, possibly due to the salmon proteins affecting the activity of the

513 inhibitory phenolic compounds. Also, Painter et al., (1998), proposed three mechanisms 514 for the inhibitory action of the carbonyls, were Type A involving the isolation of amino 515 acids or ammonia by condensation with the carbonyl compounds, Type B is effective 516 against putrefactive bacteria or molds and Type C, were through chemical changes the 517 substrate becomes less approachable and open to the microbial enzymes. Nevertheless, 518 the exact mechanism of inactivation remains unknown and both phenols and carbonyls 519 seem to inhibit bacteria.

520 Our results showed that HHP treatment (200 MPa, $15 \mathrm{~min}$ ) or treatment with $0.50 \%$ 521 liquid smoke on their own could not inactivate L. monocytogenes in already smoked 522 trout fillets $(<0.30 \log \mathrm{CFU} / \mathrm{g}$ reduction). However, when HHP treatment was carried 523 out after freezing, the samples that were treated with liquid smoke showed a synergistic 524 effect indicated by an impressive $5.48 \log \mathrm{CFU} / \mathrm{g}$ reduction (Fig. 5). This was more 525 than $5.00 \log$ reduction of CFU/g of the most tolerant L. monocytogenes strain, in 
compliance with USFDA (2000) requirements for novel technologies. It should be stated that levels of smoke in this experiment could be close to the highest limits as we added this low concentration of $0.50 \%$ (manufacturer's maximal dosage is $2.91 \%$ for processed fish) to an already smoked product. We decided to add a small amount of

530 liquid smoke to an already smoked product, to further enhance antimicrobial effects 531 without affecting the organoleptic characteristics. Hot smoked products are frequently contaminated with L. monocytogenes and due to the long period of storage and the lack of antagonistic microflora (Lianou \& Sofos, 2007), the pathogen can grow and multiply

534 during storage at refrigeration temperatures, creating an increased risk of infection for 535 the consumers (Jemmi \& Keusch, 1992). In a recent study, Hokkanen et al. (2018), analyzed 80 smoked fish products using an accredited gas chromatography-tandem MS to determine benzo[ $[a]$ pyrene and PAH4 levels and found that the mean concentrations were below the maximum levels. This confirms that the levels of smoke in our experiment could be even lower than the maximum, or if higher not significantly higher

540 than the maximum. Visciano et al. (2008), showed that after smoking treatment of trout 541 fillets, with traditional flue gas smoking and use of liquid smokes, the PAH concentrations did not increase.

543 Our experiments indicate a major synergistic effect of all three hurdles used in this work 544 and this is highly important as it could be exploited in further work which could set the 545 actual parameters, resulting in a process that could be used by the food industry. It 546 should be stated here that L. monocytogenes is of particular concern to ready-to-eat 547 smoked fish products (Acciari et al., 2017; Rodrigues et al., 2017). HHP lethality 548 depends on both food composition and technological parameters and these factors can 549 act synergistically (Bucur et al., 2018). Interestingly, by the combination of freezing 550 and liquid smoke we managed to reduce the levels of pressure to one of the lowest used 
551 in the industry which can translate into reduced costs for HHP which, however, still 552 remains expensive in comparison with other conventional methods (Elamin et al., 553 2015).

554 It is well known that bacterial cells can be injured by stresses such as freezing (El-Kest 555 and Marth, 1991). In our experiments, after freezing followed by HHP treatment, the 556 sub lethally injured L. monocytogenes cells (without liquid smoke) in smoked trout 557 fillets, were doubled comparing with the samples without freezing, something that 558 could presumably explain the synergistic effect of freezing, in combination with HHP 559 (Table 1).

560 Regarding the overall safety of the product after the addition of the liquid smoke 561 extracts it is important to mention that some of the compounds maybe contained into 562 the liquid smoke flavorings such as benzo $[a]$ pyrene $(\mathrm{B} a \mathrm{P})$, benzo[a]anthracene or other 563 PAHs are considered as potentially genotoxic and carcinogenic (Alomirah et al., 2011; 564 McDonald, 2015). Therefore, the maximum allowable concentrations need to be 565 considered for the final product. The maximum acceptable level for benzo $[a]$ pyrene $566(\mathrm{~B} a \mathrm{P})$ is $2 \mu \mathrm{g} / \mathrm{kg}$ wet weight for smoked meats, poultry and seafood established by 567 European Commission, (E.C., 2011), while for benzoates in general is $200 \mathrm{mg} / \mathrm{kg}$ for 568 smoked fish as established by the Codex Alimentarius Commission and adopted in 5692018 (Alimentarius, C., 2015) and for PAHs is $5 \mu \mathrm{g} / \mathrm{kg}$ (Varlet et al., 2007). The WHO 570 in 1994, stated that phenol intake must not exceed the $100 \mu \mathrm{g} / \mathrm{kg}$ body weight per day, 571 while there is no available data for maximum levels of carbonyls. According to 572 specifications, both liquid smoke extracts used in this study comply with the 573 Regulations. There are numerous studies showing that during smoking with liquid 574 smoke extracts instead of traditional smoking, the PAHs are no detectable or at much 575 lower concentrations than the maximum acceptable concentration in the final product 
576 (Gomaa et al., 1993; Muratore et al., 2007; Varlet et al., 2007; Dimitriadou et al., 2008;

577 McDonald, 2015).

578 As a general observation, freezing process as a pretreatment before high pressure did 579 not affect the color of our final product (raw and smoked trout). Other studies looked 580 at the differences on the color of aquacultured King salmon (Oncorhynchus 581 tshawytscha) fillets treated with combined liquid smoke and HHP treatment at $200-$ $582600 \mathrm{MPa}$ (Kong et al., 2015), frozen shrimps processed at $250 \mathrm{MPa}$ up to $10 \mathrm{~min}$ 583 (Parlapani et al., 2019) and the effect of HHP on rainbow trout (Erkan et al., 2010b) or 584 even smoked fish (Erkan et al., 2011). They reported that HHP did not change 585 significantly the color of the product. This might be important since sensory appearance 586 plays an important role for the purchase decisions by the consumers (Garber et al., 587 2003).

\section{Conclusion}

590 Combination of HHP treatment with natural preservatives such as liquid smoke extracts 591 and freezing was able to reduce considerably L. monocytogenes population on different 592 matrices, thus reinforcing food safety. High pressure treatment at $200 \mathrm{MPa}$ for $15 \mathrm{~min}$ 593 on its own caused a maximum reduction of $0.73 \log \mathrm{CFU} / \mathrm{mL}$ in number of $L$. 594 monocytogenes in BHI broth and 0.06 and $0.25 \mathrm{log}$ CFU/g on raw and hot smoked trout, 595 respectively. Freezing prior to HHP treatment enhanced the lethal effect in the presence 596 of liquid smoke extracts. When hot smoked trout fillets were treated with liquid smoke 597 condensates (L9 and G6) and freezing, followed by HHP, a remarkable $5.48 \mathrm{log}$ CFU/g 598 reduction was obtained, which shows a major synergistic effect with levels of liquid 599 smoke that comply with USFDA requirements for novel technologies. 
600

601 inactivation after a treatment at as low as $200 \mathrm{MPa}$. This high level of inactivation

There are no references in the literature reporting such a high level of L. monocytogenes

occurred by the addition of $0.50 \%$ liquid smoke to trout fillets and freezing before the HHP treatment. Even though freezing at very low temperatures, requires an additional

604 investment, products need to be kept there for just a few hours. In addition, lower costs 605 could be achieved by the low intensity of high pressures used. Also, deep freezing processes are appropriate for small scale production and development of products because of the capital cost for the nitrogen freezer is very low compared to mechanical refrigeration. Furthermore, we clearly demonstrate that with this approach we can produce new and safe RTE products at significantly reduced pressures, which could reduce remarkably the operational costs. Future studies should focus on better understanding of $\mathrm{HHP} /$ subzero temperature on food components and microbial kinetics, before its validation and acceptance from the food industry.

\section{Acknowledgements}

This research work was supported by the Onassis Foundation - Sotirios Ekonomou Scholarship ID: G ZN 043-1/2017-2018. Also, the authors would like to thank Ruitenberg Ingredients B.V. (Twello, the Netherlands) for providing all liquid smoke fractions.

\section{References}

Acciari, V. A., Torresi, M., Iannetti, L., Scattolini, S., Pomilio, F., Decastelli, L., ... \& Montagna, C. (2017). Listeria monocytogenes in smoked salmon and other smoked fish at retail in Italy: frequency of contamination and strain characterization in products from different manufacturers. Journal of food protection, 80(2), 271-278. 
625 Albertos, I., Martin-Diana, A. B., Sanz, M. A., Barat, J. M., Diez, A. M., Jaime, I., \&

626 Rico, D. (2016). Effect of high-pressure processing or freezing technologies as

627 pretreatment in vacuum fried carrot snacks. Innovative Food Science and Emerging

628 Technologies. https://doi.org/10.1016/j.ifset.2015.11.004

629 Alimentarius, C. (2015). General standards for food additives, codex stan 192-1995.

630 Pectin; Food and Agriculture Organization of the United Nations: Rome, Italy.

631 Alomirah, H., Al-Zenki, S., Al-Hooti, S., Zaghloul, S., Sawaya, W., Ahmed, N., \&

632 Kannan, K. (2011). Concentrations and dietary exposure to polycyclic aromatic

633 hydrocarbons (PAHs) from grilled and smoked foods. Food control, 22(12), 2028-

6342035.

635 Beaufort, A. (2011). The determination of ready-to-eat foods into Listeria

636 monocytogenes growth and no growth categories by challenge tests. Food Control, 637 22(9), 1498-1502.

638 Boziaris, I. S. (2014). Introduction to Seafood Processing - Assuring Quality and Safety 639 of Seafood. In: Boziaris, I. S. (Ed.), Seafood Processing. Technology, Quality \& Safety. 640 (pp. 1-6). Wiley-Blackwell.

641 Bucur, F. I., Grigore-Gurgu, L., Crauwels, P., Riedel, C. U., \& Nicolau, A. I. (2018).

642 Resistance of Listeria monocytogenes to Stress Conditions Encountered in Food and

643 Food Processing Environments. Frontiers in Microbiology, 9.

644 Bulut, S., (2014a). The Effects of High-Pressure Processing at Low and Subzero

645 Temperatures on Inactivation of Microorganisms in Frozen and Unfrozen Beef Mince

646 Inoculated with Escherichia coli Strain ATCC 25922. Food and Bioprocess Technology

$647 \quad 7,3033-3044$. 
648 Bulut, S. (2014b). Inactivation of Escherichia coli in milk by high pressure processing

649 at low and subzero temperatures, High Pressure Research: An International Journal, $650 \quad 34: 4,439-446$.

651 Carpentier, B., \& Cerf, O. (2011). Persistence of Listeria monocytogenes in food 652 industry equipment and premises. International journal of food microbiology, 145(1), $6531-8$.

654 Choi, M. J., Min, S. G., \& Hong, G. P. (2008). Effect of high pressure shift freezing 655 process on microbial inactivation in dairy model food system. International journal of 656 food engineering, 4(5).

657 Dimitriadou, D., Zotos, A., Petridis, D., \& Taylor, A. K. D. (2008). Improvement in the 658 production of smoked trout fillets (Salmo gairdnerii) steamed with liquid smoke. Food 659 Science and Technology International, 14(1), 67-77.

660 Dykes, G. A. (1999). Physical and metabolic causes of sub-lethal damage in Listeria 661 monocytogenes after long-term chilled storage at $4{ }^{\circ} \mathrm{C}$. International Journal of Food 662 Microbiology, 87, 915-922.

663 El-Kest, S. E., \& Marth, E. H. (1991). Strains and suspending menstrua as factors 664 affecting death and injury of Listeria monocytogenes during freezing and frozen 665 storage. Journal of dairy science, 74(4), 1209-1213.

666 Elamin, W. M., Endan, J. B., Yosuf, Y. A., Shamsudin, R., \& Ahmedov, A. (2015). 667 High Pressure Processing Technology and Equipment Evolution: A Review. Journal of 668 Engineering Science \& Technology Review, 8(5).

669 Erkan, N., Üretener, G., \& Alpas, H. (2010a). Effect of high pressure (HP) on the 670 quality and shelf life of red mullet (Mullus surmelutus). Innovative Food Science \& 671 Emerging Technologies, 11(2), 259-264. 
672 Erkan, N., Alpas, H., Üretener, G., Selcuk, A., Buzrul, S. (2010b). Changes in the 673 physicochemical properties of high pressure treated rainbow trout. Archiv für 674 Lebensmittelhygiene, 61(5), 183-188.

675 Erkan, N., Üretener, G., Alpas, H., Selçuk, A., Özden, Ö., \& Buzrul, S. (2011). The 676 effect of different high-pressure conditions on the quality and shelf life of cold smoked 677 fish. Innovative Food Science \& Emerging Technologies, 12(2), 104-110.

678 European Commission, E. C. (2011). Commission Regulation (EU) No 835/2011 of 19 679 August 2011 amending Regulation (EC) No 1881/2006 as regards maximum levels for 680 polycyclic aromatic hydrocarbons in foodstuffs. Official Journal of the European 681 Union, 215(4), 1-5.

682 European Food Safety Authority (EFSA). (2007). Findings of the efsa data collection 683 on polycyclic aromatic hydrocarbons in food. EFSA Journal, 5(9), 33r.

684 European Food Safety Authority (EFSA). (2015). The European Union summary report 685 on trends and sources of zoonoses, zoonotic agents and food-borne outbreaks in 2014. 686 EFSA Journal 13, 4329.

687 European Food Safety Authority, \& European Centre for Disease Prevention and 688 Control. (2015). The European Union summary report on trends and sources of 689 zoonoses, zoonotic agents and food-borne outbreaks in 2013. EFSA Journal, 13(1), 6903991.

691 Evans, J. A. (Ed.). (2009). Frozen food science and technology. John Wiley \& Sons.

692 Oosterhuis, J. J. (1981). Double freezing of plaice. Voedingsmiddelentechnologie, 693 14(2), 11-15. Fan, L. P., Zhang, M., Xiao, G. N., Sun, J. C., \& Tao, Q. (2005). The 694 optimization of vacuum frying to dehydrate carrot chips. International journal of food 695 science \& technology, 40(9), 911-919. 
696

697

698 February 2019].

699 Fasano, E., Yebra-Pimentel, I., Martínez-Carballo, E., \& Simal-Gándara, J. (2016).

700 Profiling, distribution and levels of carcinogenic polycyclic aromatic hydrocarbons in

701 traditional smoked plant and animal foods. Food Control, 59, 581-590.

702 Ferreira, V., Wiedmann, M., Teixeira, P., \& Stasiewicz, M. J. (2014). Listeria 703

FAO. (2018). The State of the World Fisheries and Aquaculture. Food and Agriculture Organization, Rome, Italy. http://www.fao.org/3/I9540EN/i9540en.pdf [accessed 08 Ferreira, V., Wiedmann, M., Teixeira, P., \& Stasiewicz, M. J. (2014). Listeria monocytogenes persistence in food-associated environments: epidemiology, strain characteristics, and implications for public health. Journal of food protection, 77(1), $150-170$

Food and Drug Administration. (2000). Kinetics of microbial inactivation for alternative food processing technologies. FDA Center for Food Safety and Applied Nutrition report-A report of the IFT for the FDA of the US Department of Health and Human Services. June 2.

Fernández, P. P., Sanz, P. D., Molina-García, A. D., Otero, L., Guignon, B., \& Vaudagna, S. R. (2007). Conventional freezing plus high pressure-low temperature treatment: Physical properties, microbial quality and storage stability of beef meat. Meat Science, 77(4), 616-625.

Garber Jr, L. L., Hyatt, E. M., \& Starr Jr, R. G. (2003). Measuring consumer response to food products. Food Quality and Preference, 14(1), 3-15.

Georget, E., Sevenich, R., Reineke, K., Mathys, A., Heinz, V., Callanan, M., ... \& Knorr, D. (2015). Inactivation of microorganisms by high isostatic pressure processing in complex matrices: a review. Innovative Food Science \& Emerging Technologies, 27, 1-14. 
720 Golden, D. A., Beuchat, L. R., \& Brackett, R. E. (1988). Inactivation and injury of

721 Listeria monocytogenes as affected by heating and freezing. Food Microbiology, 5(1), $722 \quad 17-23$

723 Gomaa, E. A., Gray, J. I., Rabie, S., Lopez-Bote, C., \& Booren, A. M. (1993). 724 Polycyclic aromatic hydrocarbons in smoked food products and commerical liquid 725 smoke flavourings. Food Additives \& Contaminants, 10(5), 503-521.

726 Hattula, T., Elfving, K., Mroueh, U. M., \& Luoma, T. (2001). Use of liquid smoke 727 flavouring as an alternative to traditional flue gas smoking of rainbow trout fillets 728 (Oncorhynchus mykiss). LWT-Food Science and Technology, 34(8), 521-525.

729 Heir, E., Møretrø, T., Simensen, A., \& Langsrud, S. (2018). Listeria monocytogenes 730 strains show large variations in competitive growth in mixed culture biofilms and 731 suspensions with bacteria from food processing environments. International journal of 732 food microbiology, 275, 46-55.

733 Hokkanen, M., Luhtasela, U., Kostamo, P., Ritvanen, T., Peltonen, K., \& Jestoi, M. 734 (2018). Critical effects of smoking parameters on the levels of polycyclic aromatic 735 hydrocarbons in traditionally smoked fish and meat products in Finland. Journal of 736 Chemistry, 2018.

737 IOFI. (2012). IOFI guidelines for the preparation of smoke flavourings. Section 15 of $738 \quad$ IOFI code of practice. Update version 1.3.

739 Jemmi, T., \& Keusch, A. (1992). Behavior of Listeria monocytogenes during 740 processing and storage of experimentally contaminated hot-smoked trout. International 741 journal of food microbiology, 15(3-4), 339-346.

742 Jiang, Z., Neetoo, H., \& Chen, H. (2011). Efficacy of freezing, frozen storage and edible 743 antimicrobial coatings used in combination for control of Listeria monocytogenes on 744 roasted turkey stored at chiller temperatures. Food microbiology, 28(7), 1394-1401. 
745 Khan, I., Tango, C. N., Miskeen, S., Lee, B. H., \& Oh, D. H. (2017). Hurdle technology:

746 A novel approach for enhanced food quality and safety-A review. Food Control, 73, $747 \quad 1426-1444$.

748 Knorr, D., Schlueter, O., \& Heinz, V. (1998). Impact of high hydrostatic pressure on 749 phase transitions of foods. Food technology (Chicago), 52(9), 42-44.

750 Kong, K. J. W., Alçiçek, Z., \& Balaban, M. O. (2015). Effects of dry brining, liquid 751 smoking and high-pressure treatment on the physical properties of aquacultured King 752 salmon (Oncorhynchus tshawytscha) during refrigerated storage. Journal of the Science 753 of Food and Agriculture, 95(4), 708-714.

754 Koutchma, T. (2014). Emerged HPP Commercial Applications. In: Koutchma, T. (Ed.), 755 Adapting High Hydrostatic Pressure (HPP) for Food Processing Operations. (pp. 29756 33). Academic Press.

757 Ledford, C. D. (1981). U.S. Patent No. 4,298,435. Washington, DC: U.S. Patent and 758 Trademark Office.

759 Laubacher, M. E., \& Ades, S. E. (2008). The Rcs phosphorelay is a cell envelope stress 760 response activated by peptidoglycan stress and contributes to intrinsic antibiotic 761 resistance. Journal of bacteriology, 190(6), 2065-2074.

762 Leistner, L. (1992). Food preservation by combined methods. Food research 763 international, 25(2), 151-158.

764 Leygonie, C., Britz, T. J., \& Hoffman, L. C. (2012). Impact of freezing and thawing on 765 the quality of meat. Meat science, 91(2), 93-98.

766 Lianou, A., \& Sofos, J. N. (2007). A review of the incidence and transmission of 767 Listeria monocytogenes in ready-to-eat products in retail and food service 768 environments. Journal of food protection, 70(9), 2172-2198. 

P. G. (2014). Functionality of liquid smoke as an all-natural antimicrobial in food 771 preservation. Meat Science, 97(2), 197-206.

772 Liu-Ping, F., Zhang, M., \& Mujumdar, A. S. (2007). Storage stability of carrot chips. 773 Drying technology, 25(9), 1537-1543.

774 Luscher, C., Balasa, A., Fröhling, A., Ananta, E., \& Knorr, D. (2004). Effect of high775 pressure-induced ice I-to-ice III phase transitions on inactivation of Listeria innocua in 776 frozen suspension. Appl. Environ. Microbiol., 70(7), 4021-4029.

777 Lundén, J., Tolvanen, R., \& Korkeala, H. (2008). Acid and heat tolerance of persistent 778 and nonpersistent Listeria monocytogenes food plant strains. Letters in applied 779 microbiology, 46(2), 276-280.

780 Martin, E. M., O’Bryan, C. A., Lary Jr, R. Y., Griffis, C. L., Vaughn, K. L., Marcy, J. 781 A., ... \& Crandall, P. G. (2010). Spray application of liquid smoke to reduce or eliminate 782 Listeria monocytogenes surface inoculated on frankfurters. Meat science, 85(4), 640783644.

784 McDonald, S. T. (2015). Comparison of Health Risks of Smoked Foods as Compared 785 to Smoke Flavorings: Are Smoke Flavors" Healthier"?. Advances in food technology 786 and nutritional scieces, 1(6), 130-134.

787 Montazeri, N., Himelbloom, B. H., Oliveira, A. C., Leigh, M. B., \& Crapo, C. A. 788 (2013). Refined liquid smoke: a potential antilisterial additive to cold-smoked sockeye 789 salmon (Oncorhynchus nerka). Journal of food protection, 76(5), 812-819.

790 Morey, A., Bratcher, C. L., Singh, M., \& McKee, S. R. (2012). Effect of liquid smoke 791 as an ingredient in frankfurters on Listeria monocytogenes and quality attributes. 792 Poultry science, 91(9), 2341-2350. 

techniques for the food industry. Food Engineering Reviews, 6(3), 43-55.

795 Moussa, M., Perrier-Cornet, J. M., \& Gervais, P. (2006). Synergistic and antagonistic 796 effects of combined subzero temperature and high pressure on inactivation of 797 Escherichia coli. Appl. Environ. Microbiol., 72(1), 150-156.

798 Muratore, G., Mazzaglia, A., Lanza, C. M., \& Licciardello, F. (2007). Effect of process 799 variables on the quality of swordfish fillets flavored with smoke condensate. Journal of $800 \quad$ Food Processing and Preservation, 31(2), 167-177.

801 Neil, D. M. (2012). Ensuring crustacean product quality in the post-harvest phase. 802 Journal of invertebrate pathology, 110(2), 267-275.

803 Noma, S., Shimoda, M., \& Hayakawa, I. (2002). Inactivation of vegetative bacteria by 804 rapid decompression treatment. Journal of food science, 67(9), 3408-3411.

805 Novotny, L., Dvorska, L., Lorencova, A., Beran, V., \& Pavlik, I. (2004). Fish: a 806 potential source of bacterial pathogens for human beings. A review. Veterinarni 807 Medicina-UZPI (Czech Republic).

808 Olivera, D. F., \& Salvadori, V. O. (2009). Effect of freezing rate in textural and 809 rheological characteristics of frozen cooked organic pasta. Journal of Food $810 \quad$ Engineering, 90(2), 271-276.

811 Painter, T. J. (1998). Carbohydrate polymers in food preservation: an integrated view 812 of the Maillard reaction with special reference to discoveries of preserved foods in 813 Sphagnum-dominated peat bogs. Carbohydrate polymers, 36(4), 335-347.

814 Park, S. H., Hong, G. P., Min, S. G., \& Choi, M. J. (2008). Combined high pressure and 815 subzero temperature phase transition on the inactivation of Escherichia coli ATCC 816 10536. International journal of food engineering, 4(4). 

monocytogenes in frozen cooked shrimps by High Pressure Processing. IAFP,

819 Louisville, Kentucky, USA.

820 Perrier-Cornet, J. M., Tapin, S., Gaeta, S., \& Gervais, P. (2005). High-pressure 821 inactivation of Saccharomyces cerevisiae and Lactobacillus plantarum at subzero 822 temperatures. Journal of biotechnology, 115(4), 405-412.

823 Pittman, J. R., Schmidt, T. B., Corzo, A., Callaway, T. R., Carroll, J. A., \& Donaldson, 824 J. R. (2012). Effect of stressors on the viability of Listeria during an in vitro cold825 smoking process. Agriculture, Food \& Analytical Bacteriology, 2, 195-208.

826 Possas, A., Pérez-Rodríguez, F., Valero, A., \& García-Gimeno, R. M. (2017). 827 Modelling the inactivation of Listeria monocytogenes by high hydrostatic pressure 828 processing in foods: A review. Trends in food science \& technology, 70, 45-55.

829 Rastogi, N. K., \& Knorr, D. (2013). Recent developments in high pressure processing 830 offoods. Berlin: Springer.

831 Redmond, G. A., Gormley, T. R., \& Butler, F. (2003). The effect of short-and long832 term freeze-chilling on the quality of mashed potato. Innovative Food Science \& 833 Emerging Technologies, 4(1), 85-97.

834 Ritz, M., Jugiau, F., Federighi, M., Chapleau, N., \& De Lamballerie, M. (2008). Effects 835 of high pressure, subzero temperature, and $\mathrm{pH}$ on survival of Listeria monocytogenes 836 in buffer and smoked salmon. Journal of food protection, 71(8), 1612-1618.

837 Rodrigues, C. S., Sá, C. V. G. C. D., \& Melo, C. B. D. (2017). An overview of Listeria 838 monocytogenes contamination in ready to eat meat, dairy and fishery foods. Ciência 839 Rural, 47(2).

840 Sanz, P. D., \& Otero, L. (2014). High-pressure freezing. In Sun, D. W. (Ed.), Emerging 841 technologies for food processing (pp. 515-538). London: Academic Press. 
842 Schmid-Hempel, P., \& Frank, S. A. (2007). Pathogenesis, virulence, and infective dose.

$843 \quad$ PLoS pathogens, 3(10), e147.

844 Shen, T., Benet, G. U., Brul, S., \& Knorr, D. (2005). Influence of high-pressure-low845 temperature treatment on the inactivation of Bacillus subtilis cells. Innovative Food 846 Science \& Emerging Technologies, 6(3), 271-278.

847 Sofos, J. N., Maga, J. A., \& Boyle, D. L. (1988). Effect of ether extracts from condensed 848 wood smokes on the growth of Aeromonas hydrophila and Staphylococcus aureus. 849 Journal of Food Science, 53(6), 1840-1843.

850 Spence, J. T. (2006). Challenges related to the composition of functional foods. Journal 851 of Food Composition and Analysis, 19, S4-S6.

852 Su, G., Ramaswamy, H. S., Zhu, S., Yu, Y., Hu, F., \& Xu, M. (2014). Thermal 853 characterization and ice crystal analysis in pressure shift freezing of different muscle 854 (shrimp and porcine liver) versus conventional freezing method. Innovative Food 855 Science \& Emerging Technologies, 26, 40-50.

856 Su, G., Yu, Y., Ramaswamy, H. S., Hu, F., Xu, M., \& Zhu, S. (2014b). Kinetics of 857 Escherichia coli inactivation in frozen aqueous suspensions by high pressure and its 858 application to frozen chicken meat. Journal of food engineering, 142, 23-30.

859 Suñen, E., Fernandez-Galian, B., \& Aristimuño, C. (2001). Antibacterial activity of 860 smoke wood condensates against Aeromonas hydrophila, Yersinia enterocolitica and 861 Listeria monocytogenes at low temperature. Food microbiology, 18(4), 387-393.

862 Suñen, E., Aristimuño, C., \& Fernandez-Galian, B. (2003). Activity of smoke wood 863 condensates against Aeromonas hydrophila and Listeria monocytogenes in vacuum864 packaged, cold-smoked rainbow trout stored at $4{ }^{\circ} \mathrm{C}$. Food Research International, $86536(2), 111-116$. 
866 Sun-Waterhouse, D., Zhao, M., \& Waterhouse, G. I. (2014). Protein modification 867 during ingredient preparation and food processing: Approaches to improve food 868 processability and nutrition. Food and Bioprocess Technology, 7(7), 1853-1893.

869 Syed, Q. A., Buffa, M., Guamis, B., \& Saldo, J. (2016). Factors affecting bacterial 870 inactivation during high hydrostatic pressure processing of foods: A review. Critical 871 reviews in food science and nutrition, 56(3), 474-483.

872 Theobald, A., Arcella, D., Carere, A., Croera, C., Engel, K. H., Gott, D., ... \& Simon, 873 R. (2012). Safety assessment of smoke flavouring primary products by the European 874 Food Safety Authority. Trends in food science \& technology, 27(2), 97-108.

875 U.S. Food and Drug Administration. (USFDA). (2000). Kinetics of microbial 876 inactivation for alternative Food Processing Technologies. Center for Food and Safety 877 and Applied Nutrition Available from: http://www.cfsan.fda.gov/ comm/ift-toc.html 878 van den Berg, R. W., Hoogland, H., Lelieveld, H. L. M., \& Van Schepdael, L. (2001). 879 High pressure equipment designs for food processing applications. In: Ultra high 880 pressure treatments of foods (pp. 297-311). Springer, Boston, MA.

881 Van Loo, E. J., Babu, D., Crandall, P. G., \& Ricke, S. C. (2012). Screening of 882 commercial and pecan shell-extracted liquid smoke agents as natural antimicrobials 883 against foodborne pathogens. Journal of food protection, 75(6), 1148-1152.

884 Varlet, V., Serot, T., Monteau, F., Bizec, B. L., \& Prost, C. (2007). Determination of 885 PAH profiles by GC-MS/MS in salmon processed by four cold-smoking techniques. 886 Food additives and contaminants, 24(7), 744-757.

887 Vaudagna, S. R., González, C. B., Guignon, B., Aparicio, C., Otero, L., \& Sanz, P. D. 888 (2012). The effects of high hydrostatic pressure at subzero temperature on the quality 889 of ready-to-eat cured beef carpaccio. Meat science, 92(4), 575-581. 
890 Visciano, P., Perugini, M., Conte, F., \& Amorena, M. (2008). Polycyclic aromatic 891 hydrocarbons in farmed rainbow trout (Oncorhynchus mykiss) processed by traditional 892 flue gas smoking and by liquid smoke flavourings. Food and Chemical Toxicology, 893 46(5), 1409-1413.Vitt, S. M., Himelbloom, B. H., Crapo, C. A. (2001). Inhibition of 894 Listeria innocua and L. monocytogenes in a laboratory medium and cold-smoked 895 salmon containing liquid smoke. Journal of Food Safety, 21, 111-125.

896 Wang, X., Devlieghere, F., Geeraerd, A., Uyttendaele, M. (2017). Thermal inactivation 897 and sublethal injury kinetics of Salmonella enterica and Listeria monocytogenes in 898 broth versus agar surface. International Journal of Food Microbiology, 243, 70-77.

899 World Health Organization. (1994). Phenol: health and safety guide.

900 Yousef, A. E. \& Courtney, P. D. (2002). Basics of stress adaptation and implications in 901 new-generation food. In: Juneja, V. K., \& Yousef, A. E. (Eds.), Microbial stress 902 adaptation and food safety. CRC Press. Pages 10-11.

903 Zaritzky, N. (2011). Physical-chemical principles in freezing. In Sun, D.W. (Ed.), 904 Handbook of Frozen Food Processing and Packaging (pp. 3-37). Boca Raton: CRC 905 Press. 


\section{Legends to figures}

907

908 Figure 1. Population reduction of L. monocytogenes strains: (A) 10403S WT, (B) LO28

909 WT, (C) EGD-e WT, grown in BHI broth and exposed to liquid smoke fractions L9 or

910 G6, ranging from $0.50 \%$ to $1.00 \%(\mathrm{v} / \mathrm{v})$ in increments of 0.25 for $0 \mathrm{~min}, 30 \mathrm{~min}, 60$

911 min and 180 min. Control samples were grown in BHI broth without liquid smoke.

912 Values represent the mean values of three replicates analyzed twice (two technical

913 replicates); error bars represent the standard error $(n=6)$. The dashed horizontal line

914 represents the detection limit of $1.60 \operatorname{logs} \mathrm{CFU} / \mathrm{mL}$.

915

916 Figure 2. Effect of HHP on L. monocytogenes 10403S WT, LO28 WT and EGD-e WT

917 in BHI broth supplemented with $0.50 \%$ (v/v) G6 or L9 with or without NaCl. Columns

918 represent the mean values of three replicates analyzed twice (two technical replicates);

919 error bars represent the standard error $(n=6)$. Values followed by the same lowercase

920 letter within treatment are not significantly different $(\mathrm{p}>0.05)$. Different uppercase

921 letters represent significant differences among strains $(\mathrm{p}<0.05)$.

923 Figure 3. Effect of HHP on L. monocytogenes 10403S WT in BHI broth supplemented

924 with $0.50 \%(\mathrm{v} / \mathrm{v}) \mathrm{G} 6$ or $\mathrm{L} 9$ with or without $\mathrm{NaCl}$, being at room temperature $\left(20^{\circ} \mathrm{C}\right)$

925 and after freezing at $-80{ }^{\circ} \mathrm{C}$. Columns represent mean values three replicates analyzed 926 twice (two technical replicates); error bars represent the standard error $(n=6)$. Values 927 followed by the same lowercase letter within treatment are not significantly different ( $\mathrm{p}$ $928>0.05)$. Different uppercase letters represent significant differences among treatments 929 with or without freezing $(\mathrm{p}<0.05)$. HHP processing temperature measured through 930 PTM was set at $0{ }^{\circ} \mathrm{C}$ at the start of pressurization. 
932 Figure 4. Effect of HHP on L. monocytogenes 10403S WT, in raw trout fillets, 933 supplemented with $0.50 \%$ (v/v) G6 or L9 with or without $\mathrm{NaCl}$, with or without $\mathrm{NaCl}$, 934 at room temperature $\left(20{ }^{\circ} \mathrm{C}\right)$ and after freezing at $-80{ }^{\circ} \mathrm{C}$. Columns represent the mean 935 values of three replicates analyzed twice (two technical replicates); error bars represent 936 the standard error $(n=6)$. Values followed by the same lowercase letter within treatment 937 are not significantly different $(\mathrm{p}>0.05)$. Different uppercase letters represent 938 significant differences among treatments with or without freezing $(\mathrm{p}<0.05)$. HHP 939 processing temperature measured through PTM was set at $0{ }^{\circ} \mathrm{C}$ at the start of 940 pressurization.

943 Figure 5. Effect of HHP on L. monocytogenes 10403S WT, in smoked trout fillets, 944 supplemented with $0.50 \%(\mathrm{v} / \mathrm{v}) \mathrm{G} 6$ or L9, being at room temperature $\left(20^{\circ} \mathrm{C}\right)$ and after 945 freezing at $-80{ }^{\circ} \mathrm{C}$. Columns represent the mean values of three replicates analyzed 946 twice (two technical replicates); error bars represent the standard error $(n=6)$. Values 947 followed by the same lowercase letter within treatment are not significantly different ( $\mathrm{p}$ $948>0.05)$. Different uppercase letters represent significant differences among treatments 949 with or without freezing $(\mathrm{p}<0.05)$. HHP processing temperature measured through 950 PTM was set at $0{ }^{\circ} \mathrm{C}$ at the start of pressurization. 
953 Table 1. Percentage (\%) of injury of L. monocytogenes 10403S WT, in BHI broth, raw and

954 smoked trout chunks, pressurized at $200 \mathrm{MPa}$ for 15 min with liquid smoke extracts G6 or L9

$9550.50 \%(\mathrm{v} / \mathrm{v})$ in combination with or without freezing at $-80{ }^{\circ} \mathrm{C}$.

\begin{tabular}{|c|c|c|c|c|c|c|}
\hline \multirow[b]{2}{*}{ Inoculum } & \multicolumn{3}{|c|}{ Without freezing $\left(20^{\circ} \mathrm{C}\right)$} & \multicolumn{3}{|c|}{ With freezing at $-80^{\circ} \mathrm{C}$} \\
\hline & BHI Broth & Raw trout & Smoked trout & BHI broth & Raw trout & Smoked trout \\
\hline \multicolumn{7}{|l|}{$-\mathrm{NaCl}$} \\
\hline $\mathrm{Lm}$ & B $3.26 \pm 4.23^{\mathrm{a}}$ & ${ }^{\text {в }} 10.87 \pm 3.56^{\mathrm{b}}$ & ${ }^{\mathrm{A}} 14.31 \pm 1.23^{\mathrm{b}}$ & ${ }^{A} 55.98 \pm 8.64^{d}$ & A $38.58 \pm 8.37^{\text {cd }}$ & В $38.59 \pm 3.15^{\mathrm{c}}$ \\
\hline $\mathrm{Lm}+\mathrm{L} 9$ & ${ }^{\mathrm{AB}} 26.58 \pm 12.81^{\mathrm{abc}}$ & ${ }^{\mathrm{AB}} 14.41 \pm 5.25^{\mathrm{a}}$ & ${ }^{\mathrm{A}} 19.47 \pm 9.47^{\mathrm{ab}}$ & A $43.79 \pm 17.56^{\text {cd }}$ & A $26.92 \pm 5.61^{\mathrm{bcd}}$ & ${ }^{\mathrm{A}} 0.00 \pm 0.00^{\mathrm{d}}$ \\
\hline $\mathrm{Lm}+\mathrm{G} 6$ & A $51.49 \pm 19.82^{\mathrm{ab}}$ & $\mathrm{A} 32.79 \pm 10.11^{\mathrm{a}}$ & ${ }^{\mathrm{A}} 24.16 \pm 7.31^{\mathrm{a}}$ & A $37.08 \pm 18.88^{\mathrm{ab}}$ & A36.64 $\pm 15.24^{\mathrm{ab}}$ & ${ }^{\mathrm{A}} 0.00 \pm 0.00^{\mathrm{d}}$ \\
\hline \multicolumn{7}{|l|}{$+\mathrm{NaCl}$} \\
\hline $\mathrm{Lm}$ & B $3.00 \pm 3.27^{\mathrm{a}}$ & АВ $29.13 \pm 13.93^{\mathrm{b}}$ & - & A $55.23 \pm 3.93^{\mathrm{c}}$ & A $38.95 \pm 10.75^{\mathrm{bc}}$ & - \\
\hline $\mathrm{Lm}+\mathrm{L9}$ & ${ }^{\mathrm{AB}} 15.12 \pm 4.81^{\mathrm{a}}$ & ${ }^{\mathrm{B}} 10.94 \pm 0.89^{\mathrm{a}}$ & - & ${ }^{\mathrm{A}} 55.86 \pm 1.24^{\mathrm{c}}$ & A $36.11 \pm 5.58^{\mathrm{b}}$ & - \\
\hline $\mathrm{Lm}+\mathrm{G} 6$ & ${ }^{\mathrm{A}} 25.24 \pm 22.14^{\mathrm{ab}}$ & ${ }^{\mathrm{B}} 8.98 \pm 2.06^{\mathrm{a}}$ & - & ${ }^{\mathrm{A}} 49.42 \pm 10.92^{\mathrm{b}}$ & $\mathrm{A} 35.13 \pm 10.14^{\mathrm{b}}$ & - \\
\hline
\end{tabular}

$956 \quad$ Lm: Listeria monocytogenes10403S WT

957 Values (mean \pm standard deviation. $\mathrm{n}=6$ ) followed by different uppercase letter in the same column are

958 significantly different $(\mathrm{P}<0.05)$.

959 Values (mean \pm standard deviation. $\mathrm{n}=6$ ) followed by different lowercase letter in each row are

960 significantly different $(\mathrm{P}<0.05)$.

961

962 
964
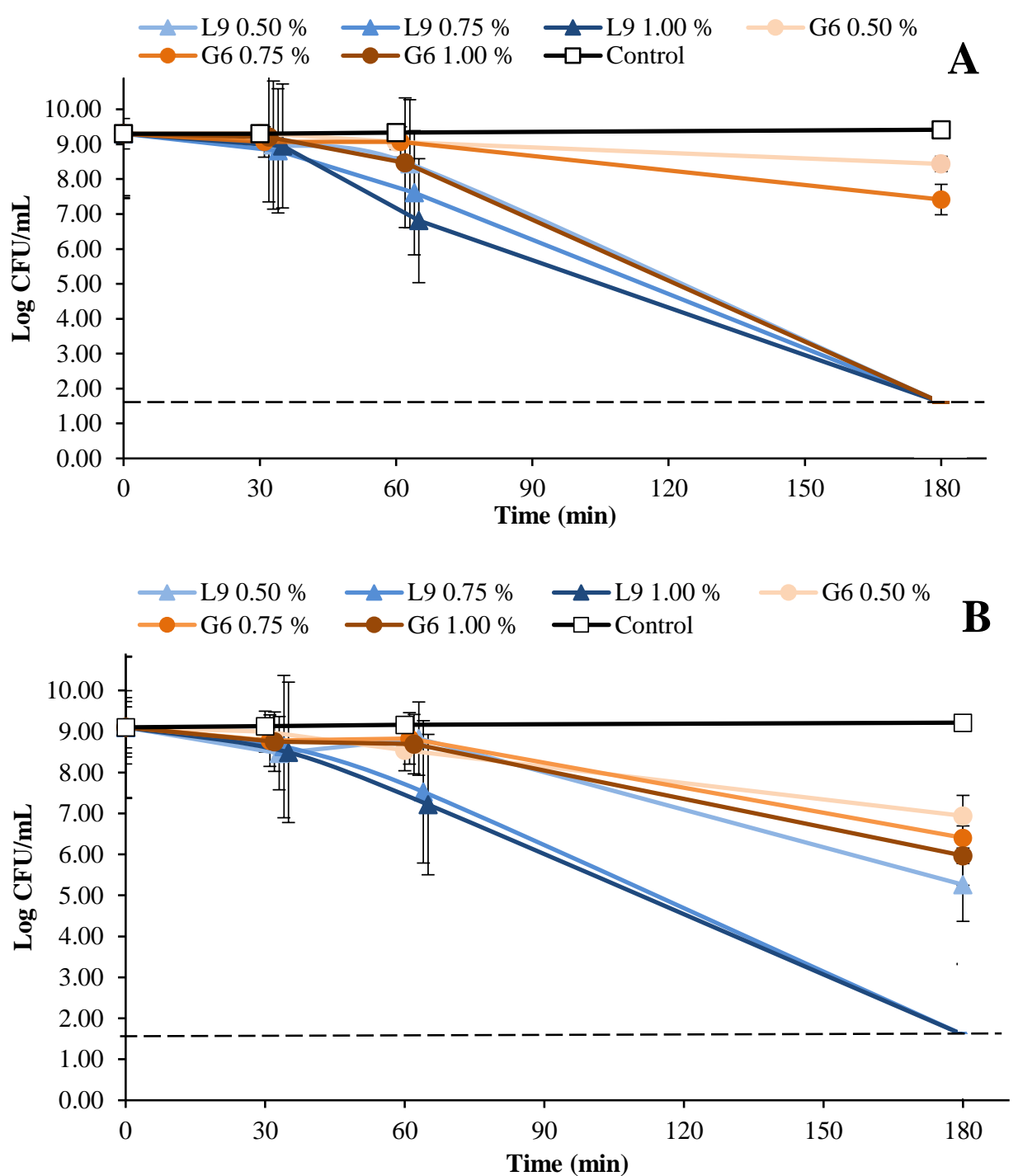

965

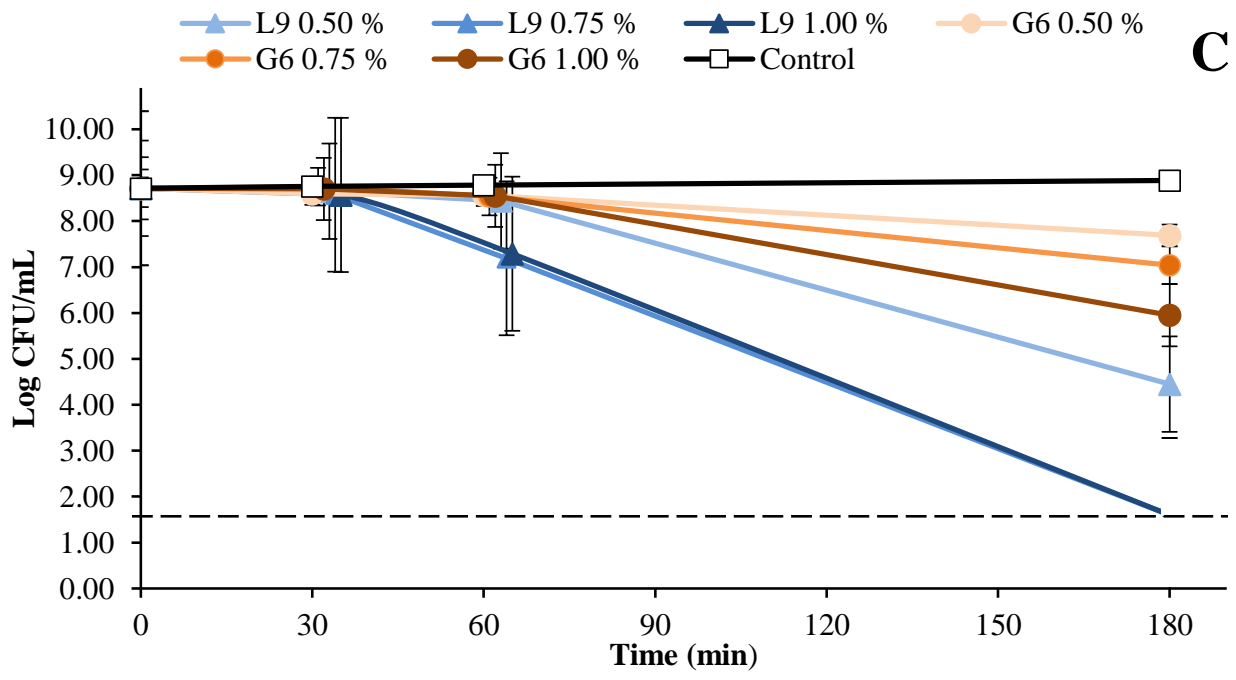




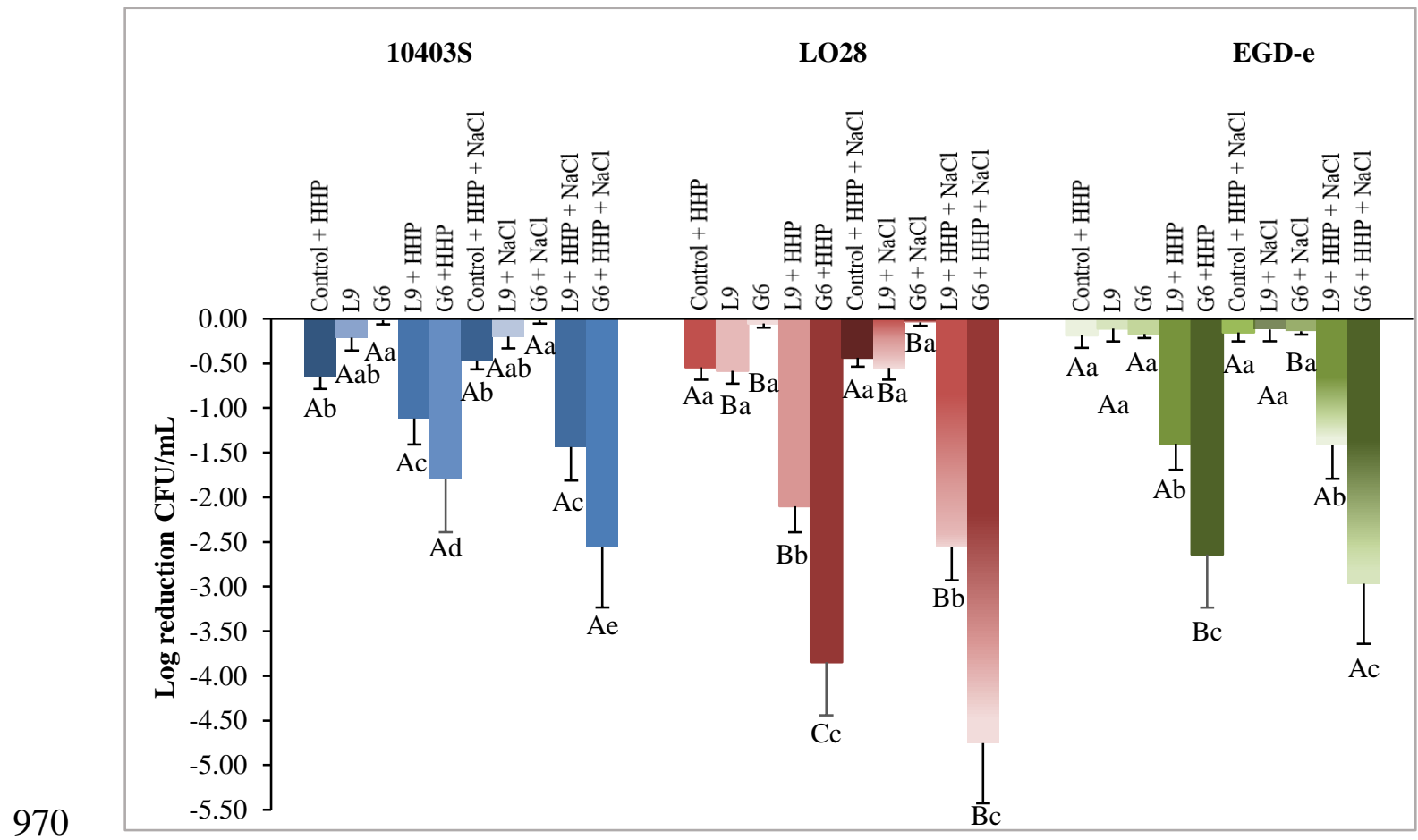

971

972

973

974

975

976

977

978

979

980

981

982

983 


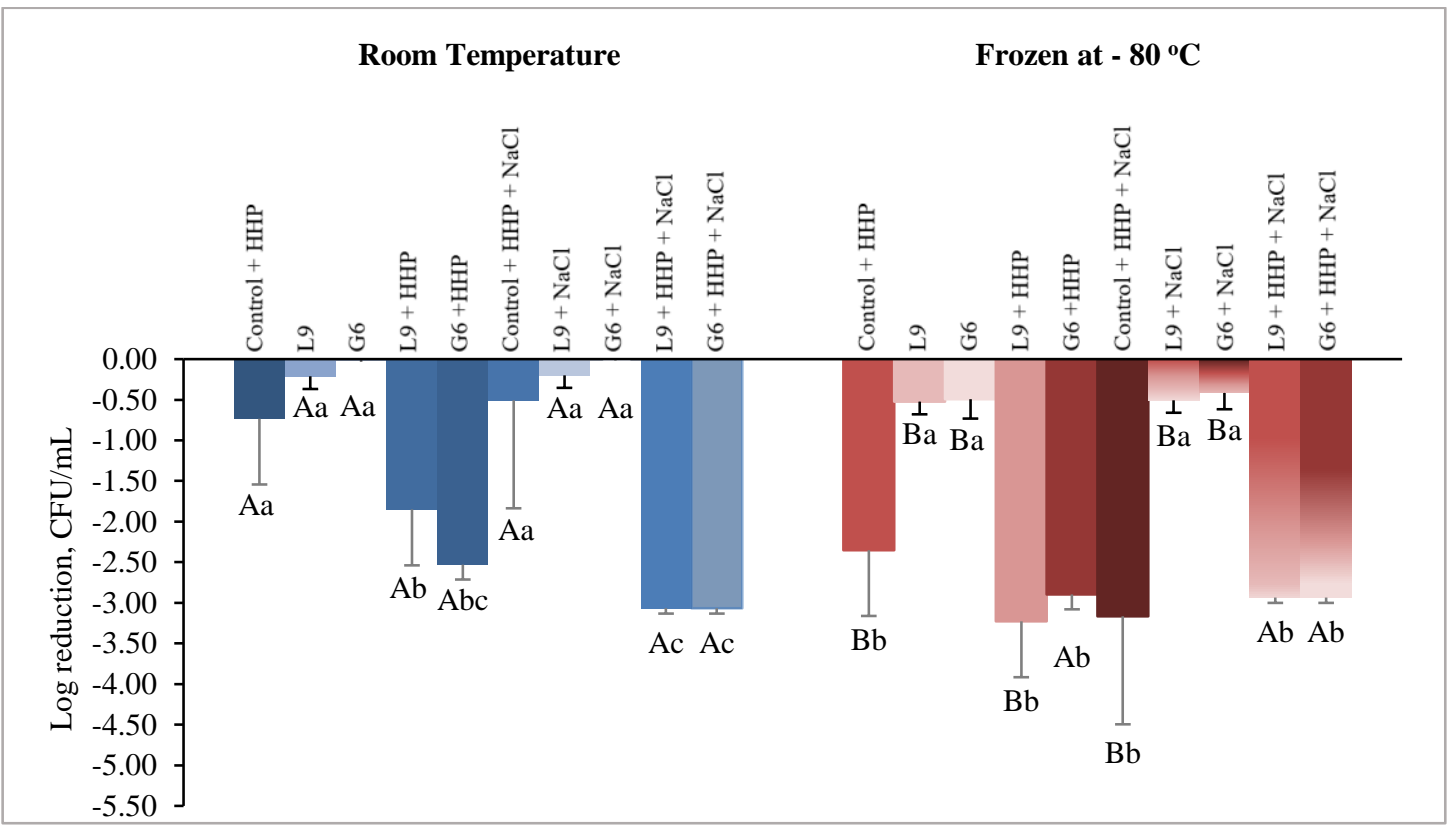

987

988

989

990

991

992

993

994

995

996

997

998

999

1000 
1002

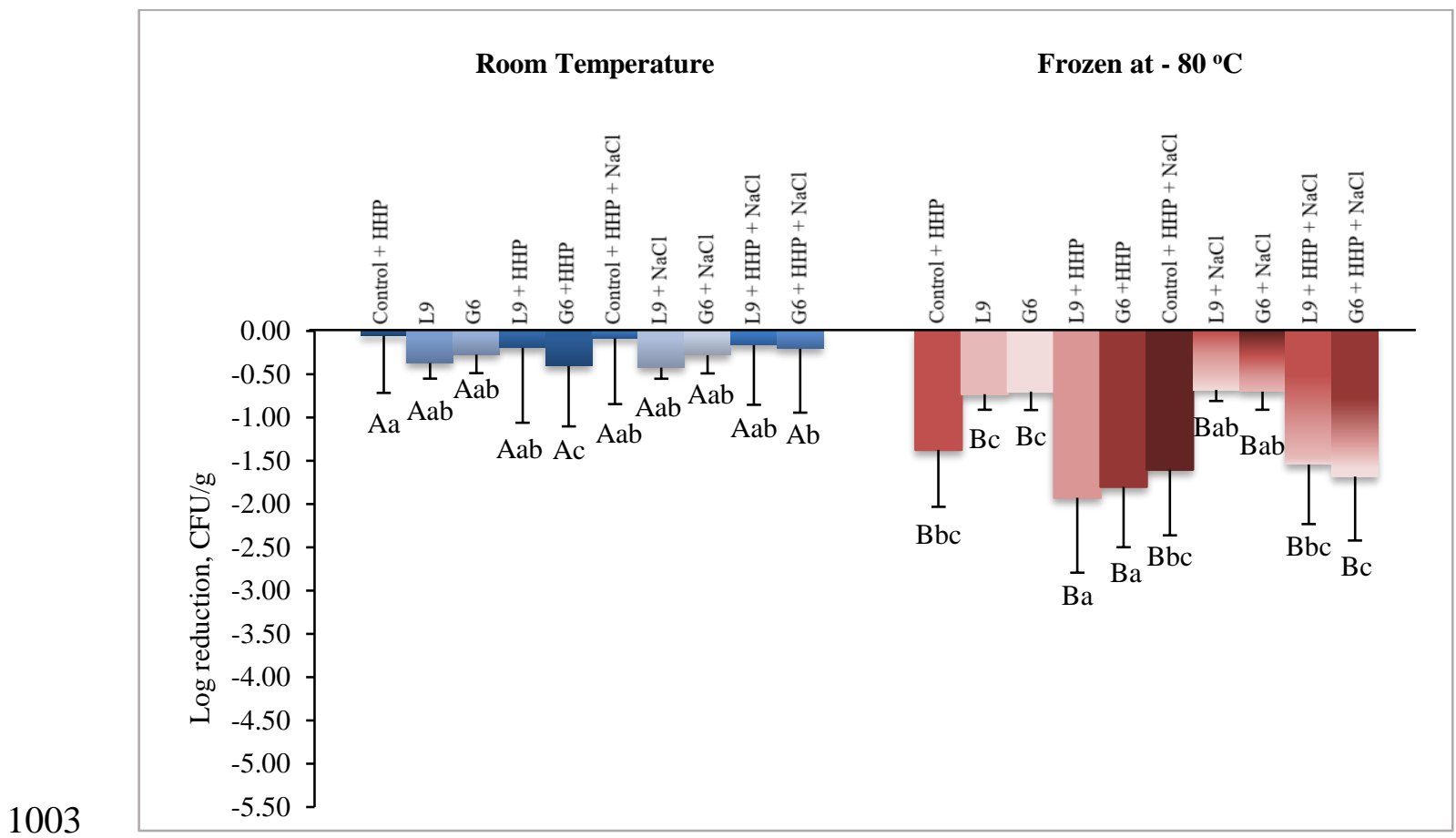

1004

1005

1006

1007

1008

1009

1010

1011

1012

1013 
FIG 5

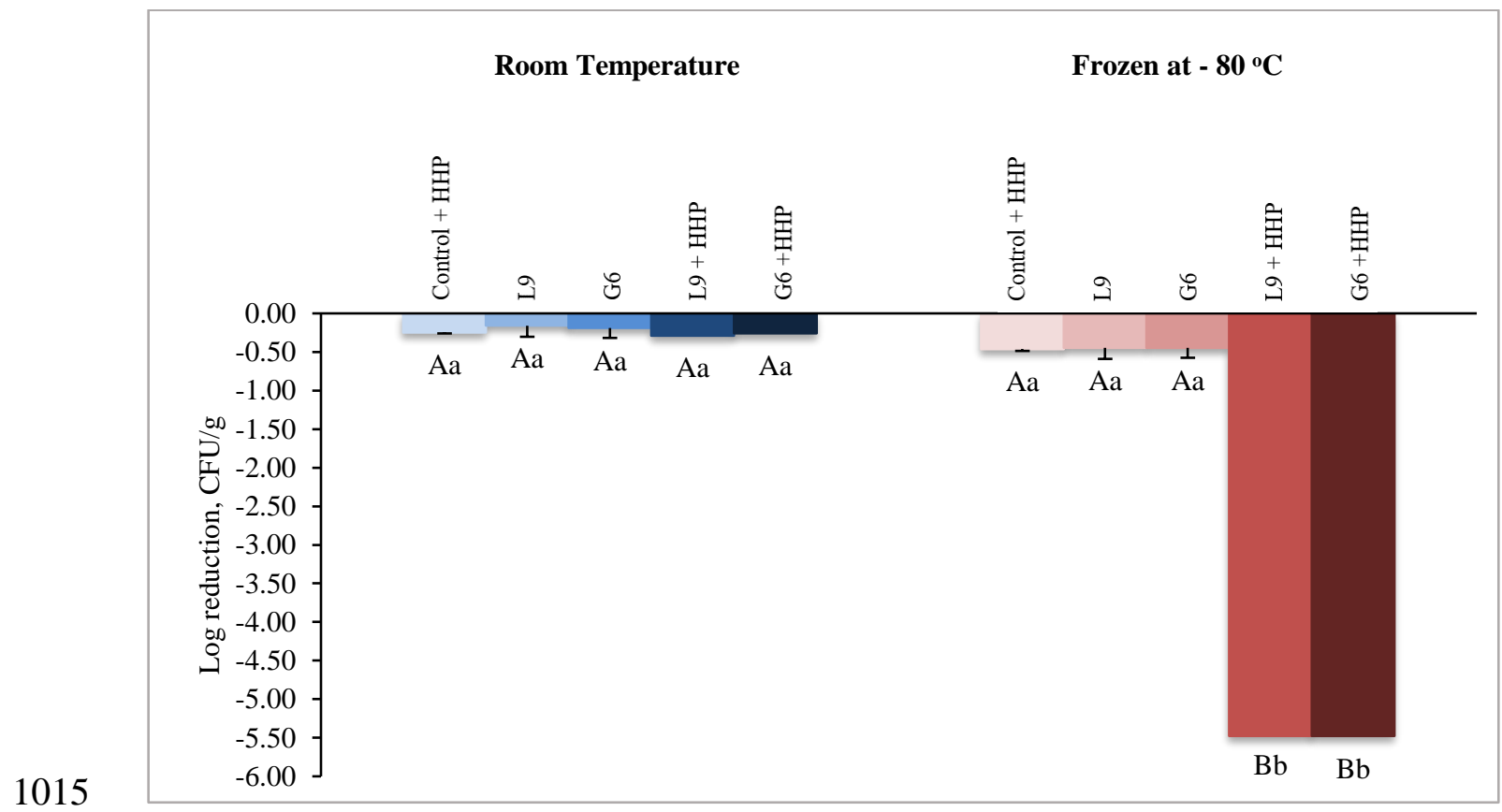

1016

1017

1018

1019

1020

1021

1022

1023 
1024 Supplementary materials

1025

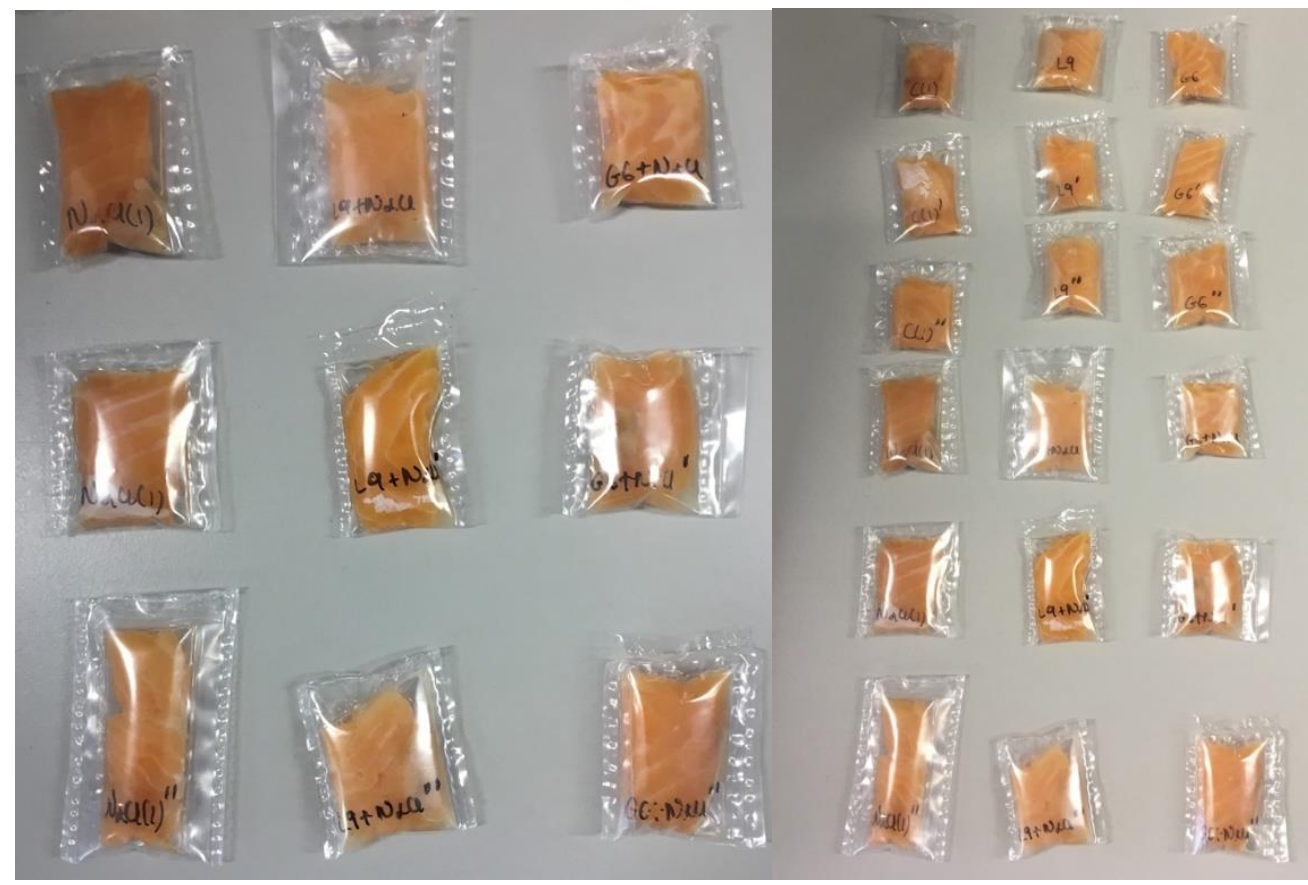

1026 Raw trout samples before HHP at 200 MPa for 15 min.

1027 

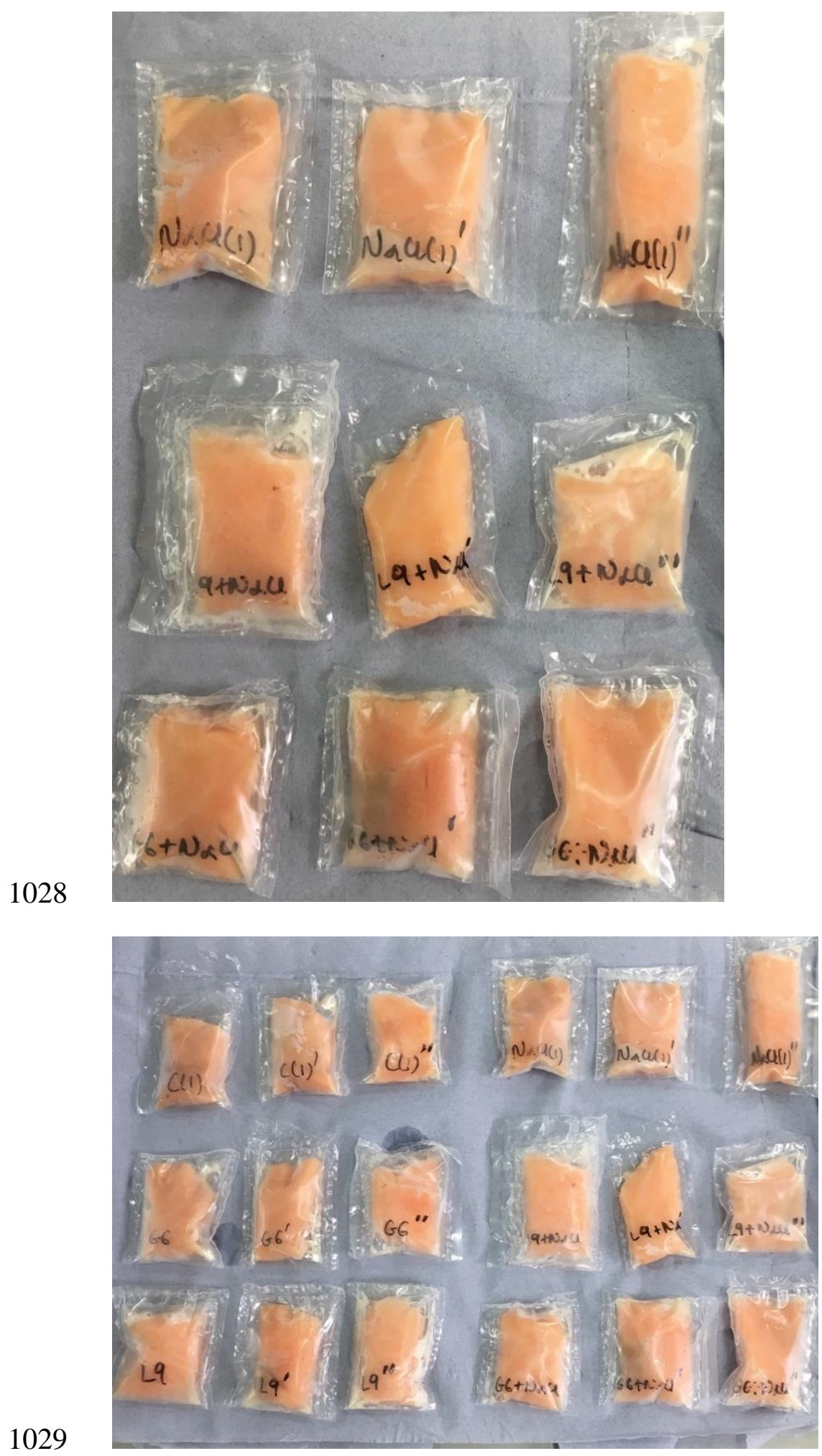

1030 Raw trout samples after HHP at 200 MPa for 15 min.

1031 
1032

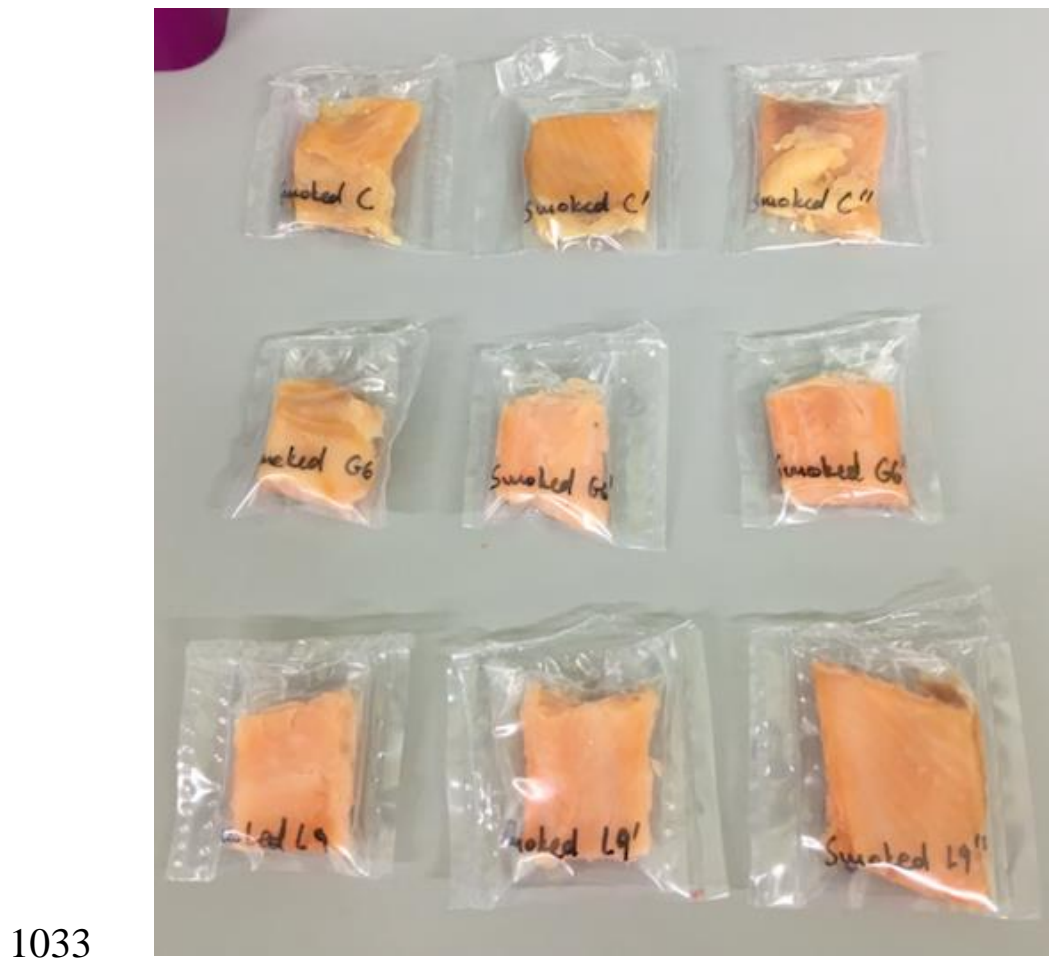

1034 Smoked trout samples before HHP at 200 MPa for 15 min.

1035

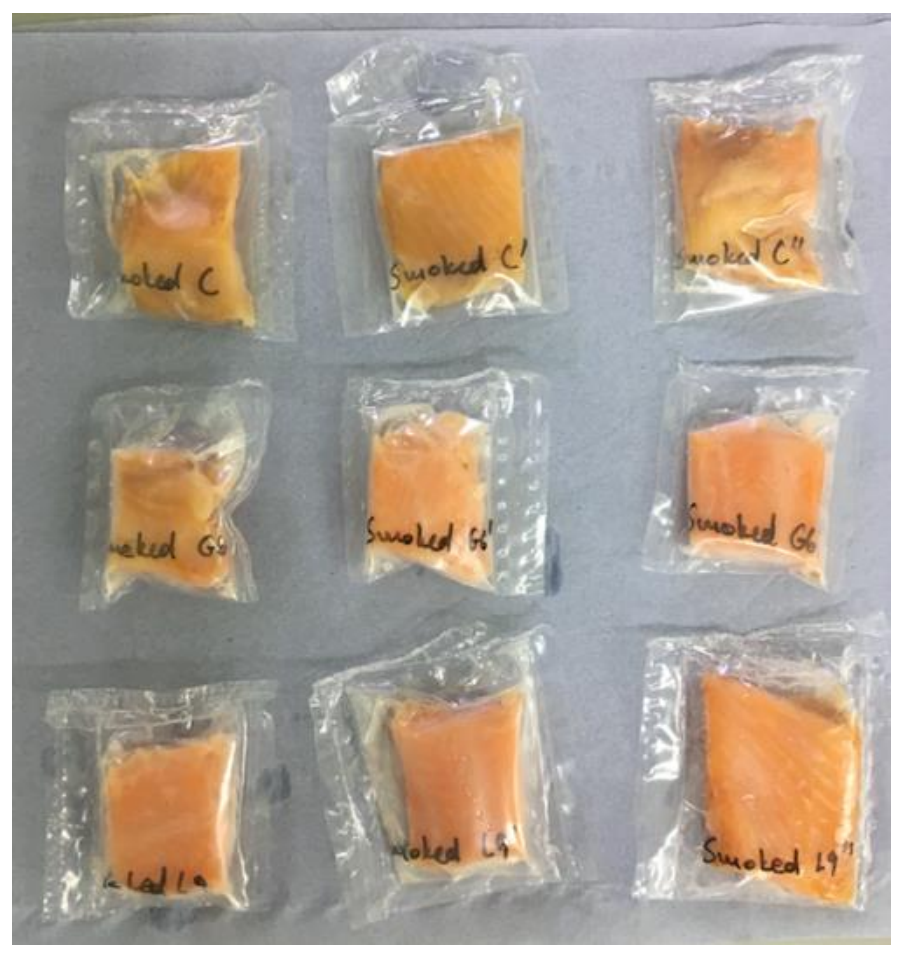

1036 Smoked trout samples after HHP at 200 MPa for 15 min.

1037 